\title{
Criminal Justice Reform in the Xi Jinping Era
}

Sarah Biddulph*, Elisa Nesossi* and Susan Trevaskes

\section{Contents}

Criminal Justice Reform in the Xi Jinping Era

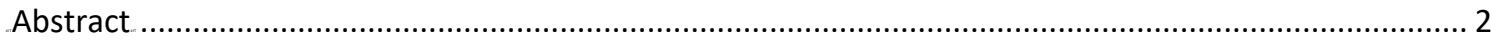

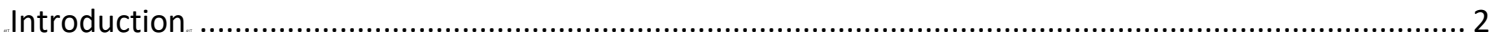

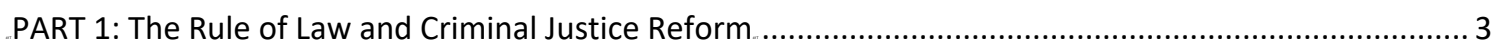

Xi Jinping's Agenda as a Reaction to Hu Jintao Era Governance ..................................................... 3

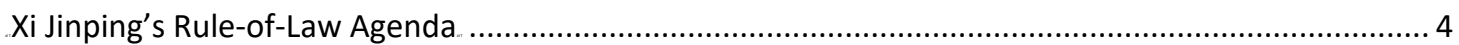

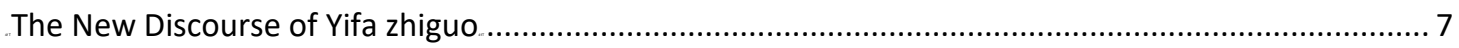

The Third and Fourth Plenum Justice System Reforms ......................................................... 7

Deepening Reforms through the Leading Group and through Pilot Programs .................................9

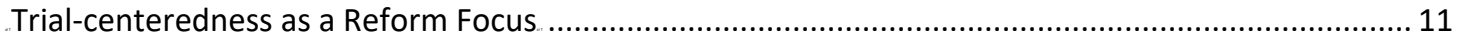

The Limited Role of Criminal Defense Lawyers ............................................................................ 12

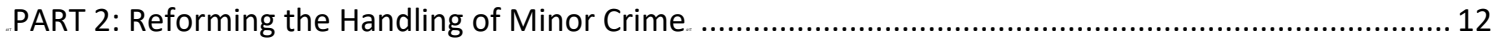

Minor Crime and Expedited Handling of Minor Offending ............................................................ 13

The changing balance between administrative and criminal powers in the system of punishments ....14

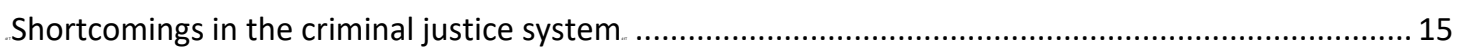

Pilot reforms and legislative reforms to expedite handling of minor offending prior to 2014 ............ 16

Pilot Projects on Expedited Sentencing of Minor Offending 2014-2016 ....................................... 20

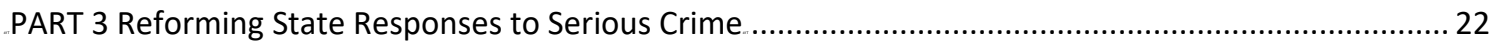

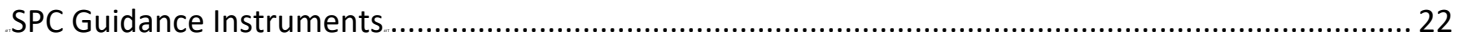

Recent Amendments to the Criminal Law to Limit the Death Penalty ........................................... 24

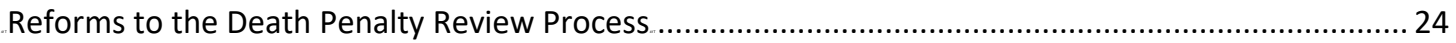

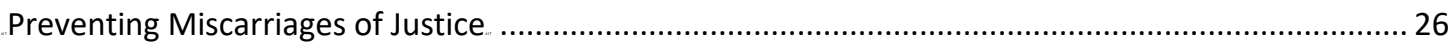

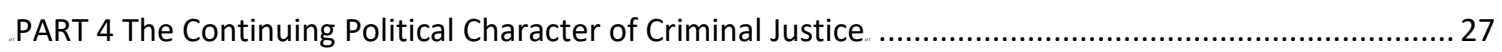

The problem with trial-centeredness as a rhetorical plea for preventing abuse of power: the extraction

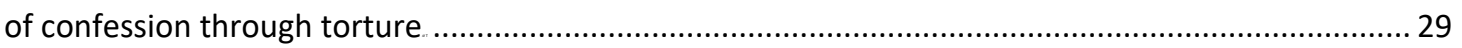

PART 5: Evaluating Reform in the Context of China's Political-Legal Culture .......................................... 31

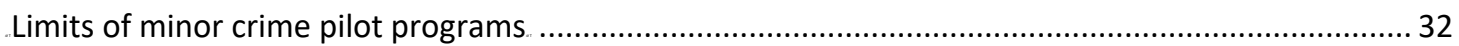

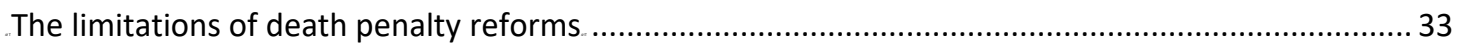

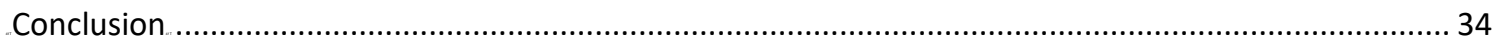

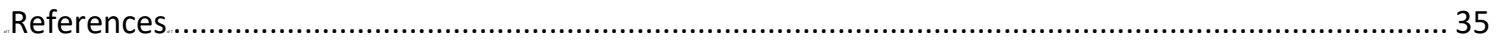




\begin{abstract}
This paper reviews current criminal justice reform initiatives that have been initiated in recent years under the governance platform yifa zhiguo or Governing the Nation in Accordance with the Law. These initiatives are helping to reframe criminal justice to correspond with Xi Jinping's broad governance intentions: finessing center-local power relations, making justice system authorities more accountable for their decision-making and improving procedures that aim to bring about greater fairness and efficiency. We examine these ongoing reforms in two main areas: the handling of minor crime and the punishment of serious offending. We find that yifa zhiguo and the reforms made in its name continue to reflect a highly legalist and instrumentalist vision of law that aims to enhance party-state governance to more effectively control dissent and crime through criminal law, to improve politico-legal institutional credibility, and ultimately, to sustain Party supremacy and social stability.
\end{abstract}

\title{
Introduction
}

In the People's Republic of China (PRC), in each main political era from Deng Xiaoping onwards, Party leaders have created political platforms that signal their intended governance agendas for the period that they are in power. These platforms also work to structure and provide a rationale for criminal justice reforms. From Deng Xiaoping's Four Modernizations to Hu Jintao's Harmonious Society, reforms have focused on dealing with social instability, social contradictions and other social problems arising as a consequence of rapid economic modernization. Whilst retaining its focus on social stability and protection of the success of economic reforms, the Decision of the Central Party Committee's Fourth Plenum of the $18^{\text {th }}$. Party Congress in October 2014 is the first in the history of the PRC to focus exclusively on Governing the Nation According to the Law (yifa zhiguo). What impact, if any has this Decision had on criminal justice reforms in the Xi era? The focus of our review is on purposes and enactment of reforms under Xi Jinping's yifa zhiguo platform.

This paper reviews developments in criminal justice in the current Xi Jinping era and scholarly analysis of these developments as they relate to the broader political platform of yifa zhiguo. We review current reform initiatives not as evidence of a teleological march from Marxism to liberal or socialist modernity but as changes championed through a political process for a political purpose. We see current day yifa zhiguo reforms as a set of innovations designed to support the current Party leadership's agendas.

Overall we find that yifa zhiguo and its accompanying political-legal rhetoric is helping to reframe criminal justice reform to correspond with $\mathrm{Xi}^{\prime}$ s broad political governance intentions. These include rebalancing political-legal control to move it away from local authorities and towards central leadership in Beijing, and standardizing decision-making across the nation under the rhetoric of enhancing both judicial fairness and efficiency. Yet the moves to recentralize power in Beijing also highlight Xi Jinping's claim that the Party's leadership must be implemented through the conduit of yifa zhiguo (Fourth Plenum Decision 2014). Hence, the yifa zhiguo agenda is ultimately connected to a highly legalist and instrumentalist vision of law since it seeks to fulfill two key political functions - enhancing the legitimacy and credibility of the regime, and controlling dissent and crime through the use of criminal law to sustain both Party supremacy and social stability nationwide.

After setting out this political context for reforms in the criminal justice system, the paper then examines two substantive areas of criminal justice; minor crime and serious crime. As we note below, these categories correspond to changes designed to address new challenges facing the criminal justice system and do not reflect categories established by legislation. This 
review focuses primarily on reforms concerning criminal legislation and institutions, considering in particular developments in the work of the courts, the police and the procuratorate, the iron triangle that dominate criminal justice. Though the law appears on its face to allocate an important role to criminal defense lawyers, particularly since amendments to the Criminal Procedure Law and the Lawyers Law, both in 2012, the position of defense lawyers has, if anything, become more precarious in the $\mathrm{Xi}$ era. Criminal defense lawyers remain the weakest party in criminal proceedings as external to the gongjianfa trifecta - the police (gong'an), the procuratorate (jianchayuan) and the courts (fayuan). In fact, the Xi regime has launched a concerted attack on those criminal defense lawyers seen as willing to provide an overly vigorous defense of their clients, with many subject to political persecution through detention, arrest, torture and criminal conviction. As we point out in the review, representation rates remain very low and, even when a suspect and defendant is represented, lawyers are very often limited in what they can do in practice.

The paper is structured in five parts. The first discusses yifa zhiguo as a political platform and how it promises to distinguish criminal justice reforms in the Xi era from the criminal justice reforms in the Harmonious Society period in the first decade of the twenty-first century. It considers the new political-legal catchphrase, placing the trial at the center (yi shenpan wei zhongxin) of the criminal justice process as a key move of this reform. The idea of trial centeredness that emerged from the Fourth Plenum document is currently used as a rhetorical device to justify and support the Xi Jinping governance agenda, particularly in relation to initiatives aimed at improving judicial fairness and efficiency. The next two parts explore how the yifa zhiguo platform applies in minor and serious criminal cases. The second part, on minor criminal case-handling, considers reforms that seek to improve the efficiency of the criminal justice system. The third part, on serious criminal case-handling, considers moves to improve judicial fairness of the criminal justice system and to prevent miscarriages of justice. The fourth considers the continuing political character of criminal justice. The final part evaluates these reforms in their current political-legal context.

\section{PART 1: The Rule of Law and Criminal Justice Reform}

Part 1 of the article offers an overview of the significance of the Rule of Law political platform under Xi Jinping. It first explains how this is linked to the Harmonious Society promoted under $\mathrm{Hu}$ Jintao and the emphasis on stability maintenance. It then discusses the link between criminal justice policies and political platforms in the Xi's era, referring to the Decisions of the Third and Fourth Plenum and the specific reforms proposed in these documents.

\section{Xi Jinping's Agenda as a Reaction to Hu Jintao Era Governance}

In the criminal justice sphere, the current regime's yifa zhiguo platform emerged in part as a reaction against some aspects of the $\mathrm{Hu}$ Jintao era Harmonious Society and Stability Maintenance agendas. One important part that does remain in place today, however, is the move in the mid-2000s to a more 'balanced' (in that it distinguishes between different types of offending and has the capacity to impose both lenient and severe punishments) regime of criminal punishment. The Harmonious Society platform began to be translated into changes in criminal justice decision-making in the mid-2000s with a movement away from a system that had often relied on harsh justice, towards a more balanced approach to criminal punishment. Promoting the idea of striking a new balance between lenient and harsh justice was a way of further removing the long-term problematic Strike Hard (Yanda) harsh justice criminal justice policy from the center stage of criminal justice (Dai 2010; Trevaskes 2010a; 2010b).

A policy of Balancing Leniency and Severity (kuanyan xiangji) that emerged in the mid-2000s had its greatest champion in the Supreme People's Court (SPC). The essential change that authorities sought to bring about through this policy was to stress the importance of 
individuating sentencing decisions, that is, to deal with each individual case by taking into account the particular circumstances of the case, rather than to apply the same or similar across-the-board light or heavy sentences for particular crime categories. In this way - in theory at least - a balance could be ensured in sentencing (Trevaskes 2010a, 2010b, 2012, 2016a). The Harmonious Society agenda influenced reforms in the treatment of serious crime in serious crime reform through the momentous death penalty reforms of 2007. On 1 January that year, the SPC regained the exclusive authority to review and approve all death sentences in China. Innovations that followed included the widespread take-up of an existing practice of criminal mediation (xingshi tiaojie) for some offenders on death row. This is a practice where offenders in some homicide cases can be given a reduced sentence if they pay the victim's family an acceptable amount of compensation (Johnson and Zimring 2009; Miao 2013; Trevaskes 2012). Reforms in the arena of minor criminal cases produced capacity for more lenient sentencing than in the past, with innovations ranging from conditional nonprosecution to the introduction of a new criminal reconciliation process in handling minor crime (Shi 2008; Trevaskes 2009; Ng and He 2016.) At the same time the system retained its commitment to severe punishment for those falling outside the parameters of lenient treatment. At both ends of the punishment spectrum, the Party's endorsement of the policy of Balancing Leniency and Severity was the driving force for change.

Synchronous with the ascendance of judicial practice reflecting the policy of Balancing Leniency and Severity the Party-state became increasingly preoccupied with problems of social instability, reshaping how the Hu Jintao leadership approached justice and government decision-making practices and security arrangements. Social contradictions produced by rapid economic growth were often expressed through widespread socially disruptive protests and strikes. Each year the number of collective protests increased. Whilst official statistics were no longer released, one assertion was the number of mass incidents, that is mass protests and riots, rose from around 10,000 in 1993 to approximately 187,000 in 2010 and 200,000 in 2012 (Fewsmith 2012; Forsythe 2011; Yang 2017). Protestors and petitioners, having no faith in local courts to deliver justice in land, labor or environmental disputes with local enterprise or government, travelled to provincial capitals or to Beijing to lodge protests (Chen 2012). Others did so because local courts routinely refused to register their administrative suits ( $\mathrm{He} 2007$ ). Moving to emphasize mediation over litigation gave local authorities greater control over case outcomes, while ensuring that relations between competing parties were harmonized.

One aspect of the strategy to localize grievances while insulating the center (Mattis 2012) enabled local courts to both refuse to accept civil cases for litigation and deal with disputes through mediation practices (He, 2007; Woo 2013; Trevaskes et. al 2014). Amongst the increasingly punitive responses to social instability was to criminalize dissent and target protest leaders for criminal prosecution (Biddulph 2015; Chen 2012; Tanner 2007). These responses to instability, coupled with direct intervention by local officials to dissipate protests, often circumvented legal processes and undermined the legitimacy of the law (Lam 2009; Minzner 2013; Trevaskes et. al 2014). The fear of social instability cast a shadow over adjudication, discouraging judges from following established trial procedure and undermining their capacity to make decisions free from local political pressure ((Liebman 2011) (Liebman 2013); (He 2007); (Su and He 2010); (Minzner 2011) Lam 2009; Rosenzweig 2013). When combined with the long-standing practices of local courts and government agencies colluding to protect the interests of local enterprises in land, labour and environmental disputes, s local protectionism (difang baohu zhuyi), the corrosive effect on the legitimacy of governance based on law was greatly exacerbated. Although the Harmonious Justice platform was touted as a way of bringing about greater fairness and efficiency, this entrenchment of local power relations worked against the idea of judicial fairness, as noted above, particularly in disputes where the local government itself had a vested interest in the outcome.

Xi Jinping's Rule-of-Law Agenda 
Criminal justice is crucial to the agendas of the Chinese Communist Party leaders, not least because it is an important instrument that incoming heads use to demonstrate how their political style differs from their predecessors. Xi Jinping was installed as Party chief in late 2012 and quickly began to tout a new political platform of Governing the Nation According to the Law (yifa zhiguo) - a platform unfolding in the criminal justice arena through stated intentions to improve judicial fairness (sifa gongzheng) and efficiency (xiaolü).

Yifa zhiguo is a political platform that signifies the Party's overall governance intentions across the term of Xi Jinping's headship of the nation. It indicates intentions to build legitimacy into the criminal justice institutions and to improve the justice system not by distancing the Party from the affairs of the justice system, but the very opposite. Party leaders in Beijing are seeking to strengthen their oversight of legal and governmental institutions in local jurisdictions so that all justice institutions operate consistently as a national system within a tight rule-of-law frame (fazhi de kuangjianei) (Trevaskes and Nesossi 2014) and implement policy more effectively and efficiently from the center down (Broadsgaard and Grunberg 2014; Clarke 2015; Li, L 2015a; Li, A. 2016; Minzner 2015; Peerenboom 2015; Seppanen 2016; Zhang 2016).

The Decision of the Party's Fourth Plenum (CCP Central Committee Decision Concerning Some Major Questions on Comprehensively Advancing the Country in Accordance with the Law) issued on 28 October 2014, states that the Party's supremacy and socialist rule of law are identical (yizhide) and that the Party will now implement its leadership role through all processes of Governing the Nation According to the Law (ba dang de lingdao guanchedao yifa zhiguo de quan guocheng). Clearly the rule-of-law envisaged in the Decision is not one that limits the role of the Party in justice affairs, but strengthens it with the intention of making the administration of justice more efficient and its individual outcomes fairer. This more Beijing-centric and Party-centric governance path can be understood as recalibrating vertical and horizontal power relations, that is, improving mechanisms for the central authorities to better control political-legal practices at the local level, and to prevent local protectionism, corruption and abuse of power, all of which produce social instability, unrest and discontent (Li, S. 2016).

The Fourth Plenum Decision includes the phrase yi shenpan wei zhongxin (placing the trial at the center) as one of the organizing principles of the justice system reforms. This idea of making the trial the centerpiece of the criminal process is translating into reforms in the criminal justice arena that seek to give more credence to collecting and presenting a greater variety of evidence that is tested through the trial process (Chen, W 2016b; Chen \& Zhou 2016; Chen et al. 2016; Long 2015; Zhou 2016). According to SPC Deputy President Shen Deyong, the main impetus for this trial-centered reform goal is to break the longstanding stronghold of investigation-centered-thinking within the criminal justice system, which equates evidence as fact with little regard for rigorous testing of that evidence at trial (Shen 2015).

This latest push to improve judicial fairness stems from a decades-old tendency in the criminal justice system to rely mainly on one type of evidence, confessions, as the key source of evidence in criminal cases. When the Xi leadership came to power in late 2012, the litany of miscarriages of justice that had been exposed throughout the previous decade was increasingly seen as a blight on the political system as well as the justice system. Remarkable 
cases included the wrongful conviction of She Xianglin, ${ }^{1}$. Nie Shubin ${ }^{2}$. and Zhao Zuohai ${ }^{3}$. among many others. Any hope of moving political-legal mindsets away from investigationcentered thinking to trial-centeredness would require the political stamp from the highest echelons of power and a fundamental shift in the deeply entrenched power disparity in the gongjianfa trifecta. Thus, the police, in particular, would have to relinquish some of their power and allow the courts to perform their allocated role in deciding cases during the actual trial, rather than pre-trial as it has been usual practice in criminal proceedings. Building credibility into the system would therefore necessitate making the prevention of miscarriages of justice a political issue.

Xi Jinping's aim of improving judicial fairness had another political purpose: to distance his leadership from the political platform of the Hu Jintao era that precipitated and embedded unfairness more deeply into the legal process in general, including the civil and criminal process. The Hu leadership's Harmonious Society platform encouraged local functionaries to favor mediation over litigation (Liebman 2011; Minzner 2013; Woo 2013). It served to move the focus even further away from trials as the center of decision-making, thus (inadvertently or not) enabling the more powerful local enterprises and government departments in disputes to influence decisions through deals, threat or bribery. Judicial credibility was lost through widespread judicial corruption at the local level (Fu 2016b). Hence post-2012, the Xi leadership's resolve was to tackle not merely miscarriages of justice in serious criminal cases through forced confession, but also more routine everyday injustices in the civil and criminal justice processes. The game plan was to make adjudication the preferred stage of the criminal process for decision-making, itself a novel idea in the administration of criminal justice since establishment of the PRC. It was also to restructure the courts in a way that they would not be so beholden to local government given that their sole source of revenue was local government. The idea was to recentralize judicial authority by way of structural change and through laws and innovations that control local judicial discretion.

At the minor crime end of the justice spectrum, the already significant increase in minor offending was further increased in 2013 with the abolition of Re-education Through Labor (laojiao). The significant increase in minor offences necessitated the creation of new ways of dealing with these cases so as not to further clog up an already overwhelmed criminal justice system. Throughout 2013 and 2014, moves intensified to speed up the handling of minor cases that in the past would have previously been handled through the Re-education Through Labor system. The reform focus here is on efficiency. Reforms purporting to improve efficiency in decision-making included new plea bargaining pilot programs, criminal reconciliation, non-custodial sentencing, conditional non-prosecution, and reforms relating to direct prosecution without arrest (Biddulph 2016; 2017).

At the serious crime end of the punishment spectrum, the political focus from 2013 onwards was on improving fairness and encouraging a greater respect for procedural justice throughout the criminal justice system (Chen J. 2016; Shen 2015). The 2012 revised Criminal Procedure Law can be interpreted in this context. Xi Jinping came into power right before the

\footnotetext{
${ }^{1}$ In 1994, She was sentenced to death for murdering his wife who was allegedly found dead; after intensive interrogation, She confessed to murdering his wife. After years of She's imprisonment and petitioning by his disgraced family, in 2005 the 'resurrected' wife reappeared.

2 The case involving Nie Shubin came to light in January 2005, when Wang Shujin confessed to the murder for which Nie had been executed ten years earlier. In 1994, Shijiazhuang police arrested Nie on charges of rape and murder and, just after a few days of 'skilful interrogation', Nie confessed, was sentenced to death, and executed. In 2005, the case was re-opened but Nie's conviction overturned only in December 2016.

${ }^{3}$ After spending in prison 11 of the 29 years of which he was sentenced, in 2010 Zhao Zuohai was exonerated for a crime he never committed when his alleged murder victim "returned from the dead".
} 
2012 Criminal Procedure Law took effect (on 1 January 2013) and many of the reforms that took place in the first years of the Xi era were already in the pipeline.

At the same time, however, the Xi leadership sought to colonize the meaning and scope within which principles of fairness, procedural justice and efficiency operated. He oversaw the launch of an unprecedented anti-corruption campaign targeting corrupt officials, not on the basis of procedural justice, but through the Party's internal discipline and inspection procedures. Only when a determination was made that the acts of corruption could not be adequately addressed through the Party disciplinary processes were these officials then fed into the criminal justice system for prosecution for serious corruption offences. (Fu 2015; Li, L. 2016). Moves were also made to eradicate alternative visions of the rule-of-law and justice that were being advocated by public intellectuals and rights protection lawyers through a targeted crack down and imposition of severe punishment (Trevaskes and Nesossi 2016).

\section{The New Discourse of Yifa Zhiguo}

In late 2012 when President Xi Jinping and his new leadership team came to power, they made efforts to distance themselves from any overt language and practice of both Harmonious Society and Stability Maintenance that had sullied the reputations and credibility of political-legal agencies in the Hu Jintao era. To make a clear break from Hu era justice, the Xi leadership began touting the importance of rule-of-law. From the beginning of 2013, political figures including Xi Jinping and Premier Li Keqiang began talking up what they called rule of law-thinking (fazhi siwei). The Xi Jinping Party leadership intended to win back the hearts and minds of the masses whose trust in the legal system was eroded by the political and judicial corruption. A series of SPC Opinions ${ }^{4}$. that first laid the groundwork for rebuilding the credibility aspect of the yifa zhiguo (Governing the Nation According to the Law) platform appeared in 2013. These Opinions included the SPC Opinion on Improving Judicial Credibility (28 October 2013), the SPC Opinion on Improving Judicial Transparency (21 November 2013) and the SPC Opinion on Preventing Miscarriages of Justice (21 November 2013) (Trevaskes and Nesossi 2014). ${ }^{5}$

According to the 2013 SPC Opinion on Building Credibility, the focus of the rebuilding credibility strategy is on standardization (guifanhua) to limit judicial discretion in local jurisdictions (SPC 2013a). In so doing, the intention is to bring a more unified approach to judicial decision-making across the nation, so that similar judgments are made for similar cases (tong'an tongpan) (Trevaskes 2014). According to this SPC Opinion, mechanisms of standardization to unify decision-making built upon the case guidance system (anli zhidao xitong) that was established in 2010 (Ahl 2014), a long-established reference case (cankao anli) system, as well as the system of sentencing guidelines introduced in 2011 (liangxing guiding) (SPC 2013a) and further improved in 2014 (Roberts and Wei 2016). The rhetoric of Xi's yifa zhiguo intentions began to progress into more concrete reform intentions through the Third and Fourth Plenum announcements which we outline below.

\section{The Third and Fourth Plenum Justice System Reforms}

\footnotetext{
${ }^{4}$ Opinions (yijian) are one of the instruments through which the SPC issues its interpretations on questions concerning specific application of laws and decrees in judicial proceedings to lower courts. Opinions are unofficially binding on lower courts. Such documents only become available through public channels when they appear on the Gazette of the SPC (Corne 2002).

${ }^{5}$ For various observations on these opinions and other SPC reforms, see the blogsite Supreme People's Court Monitor (SPC Monitor 2015; 2016a; 2016b).
} 
Justice system reform in the Xi period is tied directly to Xi's yifa zhiguo governance agenda articulated in the Party's Fourth Plenum Decision in October 2014 (Fourth Plenum Decision 2014) and to the Third Plenum Decision that preceded it in November 2013.. ${ }^{6}$

Section Nine of the 2013 Third Plenum Decision, which resolved to further promote a rule of law in China, specified three main elements of judicial reform: improving independent exercise of judicial and procuratorial power (para 32), improving the mechanism for exercise of judicial power (para 33) and improving judicial protection of human rights (including abolition of laojiao) (para 34) (Third Plenum Decision 2013). The Fourth Plenum decision sets out further detailed plans to reform both the management of judicial personnel and the court and procuratorial systems to strengthen professional standards and independence.

The Third and Fourth Plenum decisions are ambitious in their intentions to limit opportunities for local government and judicial corruption. Goals linked to this ambition include improving public credibility of justice organs, to ensure lawful, independent and fair use of its judicial and procuratorial authority to guarantee unified and accurate law implementation (Third Plenum Decision 2013). Some of the key reform promises in the 2013 and 2014 Decisions include:

- Improving ways to better guarantee that judicial powers and prosecutorial powers are exercised according to the law, independently and fairly, by reforming judicial management systems.

- Exploring the establishment of judicial jurisdiction systems that are separated from administrative areas, namely moving the financing of local courts to the provincial level.

- $\quad$ Reforming the system of adjudication committees (shenpan weiyuanhui) within courts so that those officers who preside over a trial are the same the officers who are responsible for decision-making.

- Improving transparency by encouraging open trials and open prosecutions, recording the court procedures improving judicial reasoning in court judgments and promoting access to court documents.

- $\quad$ Standardizing the system of punishment commutation, parole and medical bail procedures, and strengthening supervision systems in these areas.

- Perfecting mechanisms to prevent and correct misjudged cases, including strictly prohibiting the practice of extorting confession through torture.

- Promoting a trial centeredness outlook to improve the weight given to physical and other evidence rather than relying solely on confessions in criminal trials (Chen, $A$. 2016; Chen, J. 2016; Clarke 2015; Li, A. 2016; Li, L. 2015a; Zhang 2016).

One stand-out reform decision announced in the Third Plenum Decision of 2013 is the intention to transfer budgetary authority of local courts from the local government to the provincial level. This move, it is hoped, will discourage local judicial and government corruption. Another significant reform is the intention to reform adjudication committees internal to courts. These are decision-making committees comprising senior judges who decide difficult or complex cases. They have the power to override the opinions of a presiding judge in a case (He 2012). This reform is an example of what Peking University legal theorist Zhang Qianfan calls limited deregulation of the courtroom aimed at enhancing the ability of trial judges to decide the cases they preside over without interference (Zhang 2016, 29). The

\footnotetext{
${ }^{6}$ The core document issued from the Third Plenum is the Decision of the Central Committee of the Communist Party of China on Some Major Issues Concerning Comprehensively Deepening Reform. The Decision and its accompanying Explanatory Notes by President Xi's asserts Xi's power and intention to drive economic change and set a hard date of 2020 for completing a significant number of reforms concerning primarily political governance, security, law and economics.
} 
2014-2018 Fourth Five-Year Court Reform Plan, based on the Fourth Plenum initiatives, further supports these goals. (SPC 2015a). ${ }^{7}$. These reforms, if put into effect successfully, will give a judge much greater freedom to decide cases without interference from government officials or senior members of the court in the adjudication committee.

\section{Deepening Reforms through the Leading Group and through Pilot Programs}

Another distinctive feature of this round of judicial reform has been centralization of leadership and oversight. The Central Leading Group on Comprehensively Deepening Reforms (Shenhua gaige lingdao xiaozu), which was established in early 2014 and is headed by Party Secretary General Xi Jinping, now has final control and oversight of the judicial reform program, a function previously exercised by the Central Political-Legal Committee. This Leading Group has six specialized sub-groups, one of which, the Social System Reform Specialized Group, is in charge of the work of deepening the judicial reform (the Central Leading Group for Judicial Reform) (SPC 2016). The Supreme People's Court and High People's Courts have also established a leading group to supervise, coordinate and evaluate court reforms.

An explanatory word is warranted here about the scope of the term judicial as used in China and the powers of the judicial agencies. Whilst a western reader might automatically assume that judicial reform relates to reform of courts and judges, the concept judicial system in China is broader in scope than courts and judges. In China the judicial system commonly includes the people's courts, the people's procuratorate, public security agencies (the police) and the justice department (under the Ministry of Justice).

The procuratorates are in charge of initiating public prosecutions on behalf of the state, a role similar to public prosecution agencies in other countries. In addition to this role, the People's Procuratorate is defined in the Constitution as the state organ for legal supervision (falü jiandu) that is, as a judicial body. The Supreme People's Procuratorate has formal equal status to the Supreme People's Court. ${ }^{8}$. In exercise of its supervisory role, the procuratorate exercises broad power to supervise the conduct of trials, prisons and detention centers. Its role and organization reflect the influence of the former Soviet Union. However, its status and powers, particularly the power of general supervision, are less than those of its Soviet (and now Russian) counterpart. The officers of procuratorates are called public procurators (jianchaguan or gongsuren). Similarly, the Ministry of Justice, established under the State Council (the executive), exercises more restricted function than we might ordinarily expect from the Attorney-General's Department, or the US Justice Department. The Ministry of Justice is responsible for administration of prisons, drug detention and detoxification centers, community corrections, as well as licensing both domestic and foreign lawyers and law firms and managing the legal aid system. It does not give legal advice to other government departments or act as legal representative of the state in litigation.

The most recent wave of judicial reform plans have been drafted by provincial and equivalent level political-legal committees with input from provincial level high people's courts, procuratorates and research institutions, and so they are structured to reflect local priorities. Coordinated oversight is maintained through reporting of these plans for examination and approval to the Central Leading Group on Comprehensively Deepening Reform.. A higher degree of centralization can be seen for reforms relating to human rights protection and the mechanisms for exercising judicial power. These reports are drafted by the central Politicallegal Committee with input from the SPC and the Supreme People's Procuratorate (SPP), and are then reported to the Central Leading Group on Comprehensively Deepening Reforms. for examination and approval (Chen, W 2016a).

\footnotetext{
${ }^{7}$ For a translation of the court plan, see China Law Translate (25 February 2015). For an outline of the plan see SPC Monitor (2015).

81984 Constitution of the People's Republic of China, Articles 129-135.
} 
Another characteristic of the current round of reform is the emphasis placed on pilot projects of the proposed reforms. The National People's Congress (NPC) has delegated authority on four occasions to the SPC and the SPP to enable these pilots. The first has been to establish two circuit courts, one established in Shenzhen to handle appeal and leave-to-appeal cases from Guangdong, Guangxi and Hainan, and the other circuit court is established in Shenyang to handle appeal and leave-to-appeal cases from Heilongjiang, Jilin and Liaoning. The second occasion is to carry out pilots of expedited sentencing of minor criminal cases. The third deals with public interest civil litigation (Chen, W 2016a).. ${ }^{9}$. The fourth and latest was on 3 September 2016 when the NPC Standing Committee authorized pilots on lenient punishment where an accused acknowledges guilt and accepts a sentencing recommendation by the procuratorate (Decision on authorizing the SPC and SPP to conduct pilots on plea agreements for lenient punishment in criminal cases in some locations). Thirty-two provinces, cities' selfgoverning districts, and directly governed cities have been arranged into three groups as sites to implement reforms. The first group of seven includes Shanghai, Guangdong, Hainan, Hubei, Qinghai, Jilin and Guizhou (Chen, W. 2016a, 51). These local pilots are designed to facilitate active local engagement with reforms by enabling each locality to tailor the reforms to their own particular circumstances ${ }^{10}$. When the results of the pilots have been evaluated, decisions will be made about which mechanisms (if any) to implement nationwide.

The terms of delegation to conduct pilot reforms enable them to be handled in a way that is not entirely constrained by existing law. Overall, however, the reforms are intended to remain within the scope of existing institutional structures and laws. As a result, the changes coming out of the pilot process are more likely to be incremental rather than modeling more systematic changes to existing systems of criminal law and procedure. Many aspects of the pilots build upon existing mechanisms for improving the efficiency and timeliness of handling minor offending, such as simplified criminal procedure, criminal reconciliation, and expanding the use of bail and other coercive measures to enable an accused to remain out of custody before trial or to reduce the amount of time spent in custody before trial. Some of the reforms may be novel, with some consideration being given, for example, to the introduction of pretrial diversion programs.

Improving the efficiency of courts and procuratorates in handling cases is another important issue addressed by judicial reform. To date the issue of efficiency has been dealt with primarily as questions of time limits in handling cases and personnel reform. Personnel reform has been highly controversial and deeply unpopular. In both procuratorates and courts, personnel reform has been implemented by limiting the number of procuratorial and court personnel who are able to retain their classification as procurators and judges respectively. In courts, many of these people are now reclassified as judicial assistants or administrative personnel. The quota of people who may be classified as judges varies in different courts from 33 percent to 39 percent of court personnel. Similar provisions apply to the people's procuratorates. However, this reform has resulted in many young judges resigning as they see their chances of promotion through the judicial ranks disappear.

9 Quanguo Renmin Daibiao Duihui Changwuyuan Guanyu Shouquan Zuigao Renmin Jianchayuan Zai Bufen Diqu Kaizhan Yisusong Shidian Gongzuo de Jueding, 1 July 2015. http://www.npc.gov.cn/wxzl/gongbao/2015-08/27/content 1946100.htm. This was followed by Renmin Jianchyuan Tiqi Gongyisusong Shidian Gongzuo Shishi Banfa. 16 December 2015 http://www.spp.gov.cn/flfg/nbgz/201601/t20160108_110654.shtml

${ }^{10}$ The use of localized pilots to try out a range of reforms is a common feature of reform in China. The center tolerates, even encourages, localities to try out different ways to reform or to implement policies so that experience can be gathered and evaluated before nationwide reform programs are adopted. Such localized trials coexist with many of the recent reforms to judicial procedure that have attempted to centralize and standardize local practice, such as for example, sentencing guidelines. This dynamic balance between centralization and localization has been identified as an enduring feature of governance in China (Heilmann and Perry 2011). 
Many commentators also disagree with a purely numerical approach to restructuring courts, arguing it is misguided and fails to address the core causes of inefficiency. The renowned criminal law professor, Chen Weidong, for example argues there should be an allocation of judicial positions on the basis of case-load. He further argues that inefficiency is driven by the extraneous tasks judges and procurators are required to perform and that these tasks should be transferred to administrative personnel in the courts and procuratorates, thus freeing procurators and judges to perform their core prosecution and adjudication roles respectively (Chen, W. 2016a). Further, Chen Weidong advocates having the vast bulk of straightforward cases heard and decided by a single judge. According to this proposal, the collegiate bench would be convened only for complex cases or appeal cases (Chen, W. 2016a, 54).

\section{Trial-centeredness as a Reform Focus}

As we noted in the Introduction, a core objective of reforms is to move toward trial-centered criminal procedure. The intention is to make the trial the center of procedural system reform (shenpan wei zhongxin de songsu zhidu gaige) (Liu and Li 2016). Legal luminaries such as Chen Guangzhong, Fan Chongyi and Chen Weidong are keen to promote trial-centeredness as an integral part of Xi Jinping's Fourth Plenum reforms (Chen et al. 2016; Chen 2016c). The 2014 Fourth Plenum Decision states the objective in these terms:

Promote structural reform in litigation with trials at the center, and ensure the facts and evidence of cases under investigation, examination and prosecution can stand the test of law. Fully implement evidentiary judgment rules; collect, fix, preserve, investigate, and use evidence strictly according to the law; perfect systems for witnesses and experts appearing in court; and ensure that courtroom hearings play a decisive role in ascertaining the facts, identifying the evidence, protecting the right of action, and adjudicating impartially (Fourth Plenum Decision 2014).

China's first Criminal Procedure Law (CPL) in 1979 contained very few enforceable protections against abuse of power by criminal investigators. The amended CPL in 1996 promoted a number of reforms that paid lip service to better procedural protections, but was ultimately flawed in its capacity to enforce provisions against procedural abuse of power (Biddulph 2008). As we mentioned above, trial-centeredness is essentially aimed at shifting justice system mindsets away from an investigation-centeredness (Chen and Zhou 2016; Shen 2015). In a system where there is over a 99 per cent conviction rate, the ambition of authorities is not merely to reinstate some of the core principles of the criminal procedure system under the 1996 CPL that emphasize sound evidence as the basis for conviction, but also to cultivate a new culture of criminal justice decision-making at the prosecution and sentencing stage. This is in part to counter the tendency to give lighter sentences for cases where evidence is in doubt as an alternative to finding the suspect not-guilty of a crime. In Chinese this practice is referred to as liuyou yudi or leaving some leeway for error or doubt (Trevaskes 2012).

The trial centeredness doctrine is also aimed at countering tendencies of police to rely on confession and not on other evidence that is usually more difficult and time-consuming to obtain (Chen and Zhou 2016). SPP senior officials hope that this emerging doctrine of trial centeredness will help to erode the longstanding tendency to go heavy on fighting crime and light on protecting rights (zhong daji qing baohu), which SPP prosecutors Chen Guoqing and Zhou Ying believe still carry significant currency in policing and prosecutorial circles (Chen and Zhou 2016).

On 10 October 2016, a Joint Opinion was issued to all criminal justice organs throughout China summarizing the imperative of the current push to develop a trial-centered litigation system. The Notice entitled Opinions on Promoting the Reform of the Trial-centered Criminal Procedural System Jointly Issued by the SPC, SPP, Ministry of Public Security, Ministry of National Security, and Ministry of Justice outlines instructions on the proper collection of 
evidence and due process. This Opinion largely comprises provisions already contained in the 2012 CPL or in the SPC's 2012 Judicial Interpretation of the CPL. Nevertheless, the provisions are for the first time collected in the one document in twenty-one articles issued jointly by the key agencies responsible (Joint Opinion 2016). In February 2017, the SPC issued its 'Implementing Opinions' giving details on how courts must implement the Joint Opinion, including new rules regarding pre-trial conferences where the defense can apply for suppression of evidence related to allegations of forced confession (SPC 2017).

While confident that trial centeredness will improve the quality of investigation, prosecution and trial, SPP senior authorities are quick to point out that this is not a push to westernize the legal process. As SPP prosecutors Chen and Zhou argue, this is about trial centeredness not court centeredness. The push is to correct a strong tendency in the criminal process to downplay the importance of the trial judge's role in the criminal process. Trial-centeredness is a move to take the focus on the police's testimony and evidence dossier and place it more on the revelation of the facts through testing at trial. It is aimed at improving the quality of evidence gathering and improving the supervisory role of the prosecution in ensuring that police power is not abused. In short, the Fourth Plenum description of the trial-centered approach to justice cited above is all about ensuring that the court hearing should be the central link in the fact-finding process and that it - not the case dossier - must play the decisive role in determination of the facts of a case (Chen and Zhou 2016). The main idea is that evidence presented by the police and prosecution in a case should be determined to be a fact only after it has been tested in court. Evidence must be provided in the form of an interlocking chain through the presentation of multiple sources of evidence including calling witnesses when appropriate (Shen 2015).

\section{The Limited Role of Criminal Defense Lawyers}

Trial centeredness does not imply an increased role played by criminal defense lawyers during criminal trials. Indeed, leading legal scholars such as Chen Ruihua (2017) note that the party's interpretation of this concept basically ignores the key role of the lawyer in fostering greater opportunities for judicial fairness. The 2012 CPL allows for suspects to retain a defence lawyer at the investigative stage of the criminal process. It also allows for lawyers to meet their clients without the approval of the police in most cases, (with the exception of cases involving national security, terrorism or particularly serious crimes of bribery). It also protects against police monitoring of client-lawyer meetings in detention centers and, most notably, in theory, lawyers now have greater access to the prosecution's case dossier. However, the amended CPL still gives no right for a defense lawyer to undertake independent investigations of a case. As Guo Zhiyuan notes, this means that it remains very difficult for the defense to collect evidence to contest the prosecutions' claims via independent investigation (Guo 2014). Neither the 2016 Joint Opinion nor the 2017 SPC Implementing Opinion contains any provisions that substantially improve a suspect's access to a lawyer at the crucial stage of the process: the interrogation.

Empirical research also indicates that the role of defence lawyers in criminal proceedings remains very limited. At the pre-trial stage, lawyers still have significant difficulties in meeting their clients, accessing case files and gather evidence (Han 2015; Liu and Halliday 2016). During trial, their role is often considered a mere formality, leading some authors to define it as a pure performance without substantive value (Li 2015).

\section{PART 2: Reforming the Handling of Minor Crime}

The discussion of reforms to the criminal justice system below is divided into categories of minor and serious crime. This mode of division reflects recent reforms and pilot reforms to the functioning of the criminal justice system designed to address new challenges, rather than reflecting categories created by criminal legislation. In fact the law does not draw a distinction 
between minor and serious crime. The dramatic increase in criminal case load has forced legislators and policy makers to confront the need to make a more rational allocation of resources to deal expeditiously with simple or straightforward cases and to allocate more resources to complex and serious cases. Similarly a criminal justice policy that emphasizes efficiency and fairness cannot for long overlook the pernicious effects of holding a person who has committed a minor offence, for example a traffic offence, in detention when they are unlikely to be sentenced to a term of imprisonment, or if imprisoned for a longer period than they have already spent in detention.

This is a problem that other, foreign, jurisdictions have had to address and where it has become commonplace for the law to distinguish between procedures applied to try minor and serious crime. Examples include the distinction in common law jurisdictions between misdemeanor and felony crimes in the United State of America, between summary and indictable offences in Australia, New Zealand and the United Kingdom and comparable distinctions in European civil law jurisdictions between minor and serious crime. At its core, the distinction is designed to facilitate allocation of judicial resources to the cases that need it and to expedite handling of minor matters that are comparatively straightforward.

The Chinese criminal justice system currently does not do this well (if at all). Rising crime rates and in particular rising rates of minor offending have strained resources available to deal with criminal offending and have raised questions about how the state's resources should be best allocated to accommodate political demands that the justice system be both just and efficient. Despite the absence of a legal category of minor crime, the question of what conduct constitutes a minor crime and what procedures should be applied to handling this type of crime has become one of the central issues in criminal justice reform.

\section{Minor Crime and Expedited Handling of Minor Offending}

Instituting systems for expedited handling of minor criminal offences was included in the revised Fourth Five-Year Court Reform Plan point 12 (SPC 2015a) as a core area for reform. ${ }^{11}$. Whilst reform to expedite handling of minor offending has been conceived to encompass all agencies involved in the administration of criminal justice - police (Ministry of Public Security), procuratorate (prosecution), courts (trials), and justice agencies (legal representation and evaluation of suitability for a non-custodial sentence) - to date, judicial reform has grouped courts and procuratorates together. Police reform is slated to start later than the court and procuratorate reforms. The lack of an overarching reform program highlights both the difficulties and shortcomings in the overall judicial reform agenda. Police powers are difficult to reform. Both court and procuratorial reform have been ongoing for many years. But without coordinated reforms that address each stage of the criminal justice process, systematic reforms that might for example divert minor offenders out of the criminal justice system early, will be difficult to achieve. Failure to include the police in the current round of reforms ensures that the existing largely chronological divisions between stages of the criminal justice process, with one agency exercising primary power in respect of that stage of the process, is retained.

Inclusion of minor crime in this round of reform raises a number of preliminary issues as, to date, Chinese law contains no concept of minor crime. So, before moving to a discussion of the trials currently being undertaken, it is important to explain the evolving place of minor crime in overall patterns of offending, how attention has come to focus on minor crime, and why it has become enough of an issue to warrant being included in the reforms. Whilst noting that these specific reforms have received positive policy impetus from the criminal justice policy of Balancing Leniency and Severity and from the focus on trial-centered administration of justice, these issues have been discussed above and will not be discussed in more detail

\footnotetext{
${ }^{11}$ Promulgated to take effect from 4 February 2015. Expedited handling of minor criminal offenses is point 12 within the broader topic of establishing a trial-centered procedural system.
} 
here. Here we discuss by way of background two practical and inter-related factors that have been significant: reforms to administrative sanctioning powers and shortcomings in the criminal justice system in handling minor offending efficiently and justly.

\section{The changing balance between administrative and criminal powers in the system of punishments}

What in western-liberal democracies is encompassed within the criminal justice system, in China is divided between administrative and criminal sanctioning systems. Theoretically, the Chinese system has favored restricting the scope of conduct punished as crime (xiao xingfa guannian) (Wei 2015) and instead has punished a wide range of minor offending through the use of police administrative sanctions. However, with ongoing reforms to progressively limit the range of administrative sanctioning powers exercised by the police and reforms in criminal law, this balance in the system of punishments is in flux. Since 1996 a range of police administrative powers has been abolished or transformed into other powers, be they criminal coercive powers or welfare powers. ${ }^{12}$. The most infamous was laojiao (Re-education Through Labor), abolished at the end of 2013 (Biddulph 2016).

One significant consequence of the abolition of laojiao has been that some of the conduct previously punished administratively may now be prosecuted within the criminal justice system by virtue of the Eighth (2011) and Ninth (2015) amendments to the Criminal Law (Biddulph forthcoming 2017). Another consequence of abolition of laojiao was to focus highlevel political attention on the need to develop new mechanisms for dealing with minor offending and provided one of the main incentives for the current round of trial reforms. Prior to incorporation into the judicial reform program, Zhou Qiang, the chief judge of the SPC, had anticipated the need to establish procedures to expedite adjudication to cope with the increase in the number of minor offences handled by the courts anticipated after abolition of laojiao. On

\footnotetext{
12 These include: laojiao which enabled the police to impose a period of administrative detention for between one and three years in a wide range of circumstances including for minor offending; shourong shencha which was abolished in its existing form with corresponding changes made to the Criminal Procedure Law in 1996 to accommodate the substance of that power within police criminal coercive powers; and shourong qiansong which was substituted with a so-called welfare provision to enable undocumented migrants, vagrants and beggars to seek temporary refuge in facilities operated by the civil administration. Two other administrative powers - shourong jiaoyu, to detain sex workers and their clients (for between six months and two years) and shourong jiaoyang, to detain juvenile offenders who are not eligible for criminal sanction - are increasingly vulnerable because of their glaring inconsistency with the basic requirements of legality (Biddulph forthcoming).
}

But even though the number of administrative detention powers exercised by the police has been reduced, administrative forms of detention and punishment continue to play a significant role in the overall system of punishments. Some reforms have maintained and legislatively entrenched police administrative powers. One of the most important reforms to reduce the number of people detained in laojiao was effected by the 2008 Drug Prohibition Law. This law created two compulsory drug rehabilitation orders for offenders to serve in the community: giving up drugs in the community and recovering health in the community (shequ jiedu, shequ kangfu (Articles 33 and 48) and a sui generis detention power for the detention and treatment of drug-dependent people (Article 38) (Biddulph \& Xie 2011). Imposition of a period of detention under this law continues to be determined by the police and not by a court (Biddulph forthcoming, 2017; Biddulph and Xie 2011). Police powers to impose a period of administrative detention (xingzheng juliu) of up to twenty days is secured by the Public Security Administrative Punishments Law (Article 16) and the power to detain a person for questioning for up to forty-eight hours (liuzhi panwen) is set out in the People's Police Law (Article 9). Each of these administrative powers is discussed in the accompanying paper in this issue of China Law and Society Review. 
23 October 2013, he reported on a meeting convened to discuss court work, including its response to abolition of laojiao, urging local level courts to establish procedures for expedited handling of minor offences. ${ }^{13}$

\section{Shortcomings in the criminal justice system}

Alongside reforms to administrative sanctions that have resulted in transfer of some administrative cases into the criminal justice system, there has been an increase in minor criminal offending resulting from economic and social reform (including property offences such as petty theft, public order offences and traffic offences). Reforms to administrative sanctions and changes in offending conduct together have contributed to a significant increase in the number of minor offences handled by the courts (Shi 2015). The system currently faces a number of conceptual and institutional challenges in developing ways both to identify minor offences and to develop the procedures for handling these cases without delay and without compromising the aspirational baseline of justice. There is a perceived need to develop a mechanism to identify and allocate stretched judicial resources to handling complex and serious cases (Shi 2015). However, the system does not contain a good mechanism to identify and allocate resources to those cases. It is also necessary to ensure that straightforward cases are in fact handled quickly. The system does not do this well either.

The first problem is that there is no clear legislative distinction between minor and serious crime. At present, whilst there is still debate on the issue, a rule of thumb is that a crime is minor if a sanction of less than three years' imprisonment, or a non-custodial sanction such as a criminal fine or community corrections may be imposed. Additionally, for a case to be considered minor, the facts of the case must be straightforward and clear, the evidence sufficient and reliable, and the accused must acknowledge guilt and not dispute the applicable law (Pan 2015.). ${ }^{14}$. One estimate is that over 70 percent of criminal cases dealt with by the courts fall within this unofficial definition of a minor offense. Some suggest that this definition should also be extended to include certain categories of offenders who are eligible for lenient treatment under the policy of Balancing Leniency and Severity, including juvenile offenders, first time offenders and occasional offenders (ou fan) (Gong 2006). Although simplified procedure and criminal reconciliation (discussed below) are commonly used in practice to resolve minor offenses, their use is not limited to minor offending and so the availability of these procedures cannot of itself provide clear grounds for distinguishing between minor and serious crime.

The lack of a principled distinction between minor and serious crime is compounded by the lack of a corresponding differentiation between procedures for handling different types of cases. An all-of-system approach is required if both efficiency and justice are to be achieved to address issues at each stage of the criminal process - investigation, prosecution and adjudication - and in the relationship between these different stages. It remains common for criminal suspects to be detained until trial. Police have traditionally been reluctant to release people prior to trial on bail or on residential surveillance (in their own home as opposed to a designated location). Lack of adequate measures to distinguish between straightforward minor offenses and serious offenses often results in the vast majority of accused being held in detention for extended periods regardless of the nature of their alleged offense. In minor cases, extended

\footnotetext{
${ }^{13}$ Zuigao Fa Tichu Tansuo Wanshan Qingwei Xingan Kuaishen Kuaijie Jizhi (Explore and Perfect Rapid Adjudication of Minor Criminal Cases) 24 October 2013 at http://news.sina.com.cn/c/2013-10-24/023928515178.shtml

${ }^{14}$ This standard is found in the December 2006 SPP Opinion on Expedited Handling of Minor Criminal Cases According to the Law (Guanyu Yifa Kuaisu Banli Qingwei Xingshi Anjian de Yijian). This definition takes as its primary determinants the severity of the punishment, and the fact that the case is straightforward without contestation of facts, law or evidence. The view is that if a person does not admit guilt (which the vast majority do), then the matter cannot be straightforward and minor.
} 
pre-trial detention leads commonly to the sentence imposed being identical to the length of pretrial detention, that is, time-served sentences (Shi 2015).

At the prosecution and trial stage, addition of simplified procedure as an alternative to ordinary procedure has not successfully resolved the inefficiencies in trial procedure, nor has it adequately enabled the process to be sped up and so its use remains limited. Between 2004 and 2011 an average of only 30 percent of first instance cases were tried using simplified procedure. After the 2012 reforms to the Criminal Procedure Law, the rate increased but only to around 50 percent of cases (Liu and Li 2016). As discussed below, ordinary trial procedure is also poorly suited to the efficient handling of cases even where the accused has pleaded guilty and the evidence is uncontroversial and accepted.

So, in respect of minor offending, the number of cases understood to be minor has increased, but there is lack of clarity about the scope and boundaries of minor crime and lack of appropriate mechanisms within the criminal justice system to identify and expedite the disposal of those cases. Awareness of this problem has been growing from the mid-1990s when the first trials of simplified procedure were conducted and the first of several legislative reforms were introduced to expedite the handling of minor crime. As will also become clear in the discussion below, many of the reforms focus on shortening time limits, which if not accompanied by other reforms may not resolve problems of inefficiency and risk, and perversely, may risk exacerbating problems of injustice.

Pilot reforms and legislative reforms to expedite handling of minor offending prior to 2014

Reforms to the way minor offending was handled commenced with the first trial of simplified procedure in 1995 in the Haidian district court (Wang 2005). The next major series of reforms was launched by the SPP in its Opinion on Expedited Handling of Minor Criminal Cases according to the Law in December 2006 (SPP 2006). As part of the iterative process of trying out reforms in certain localities and enacting into legislation those pilots considered suitable for use nationwide, some initiatives have already been incorporated into the Criminal Law and Criminal Procedure Law. Some pilots are ongoing. The latest round of judicial reform builds on these earlier sets of pilots and reforms. Whilst each of the reforms discussed below comprises one element in the expedited handling of minor crime, the pilots underway between 2014 and 2016 are both broader and narrower than each of these previous reforms.

\section{Simplified procedure}

The CPL currently provides for ordinary procedure (tried with a collegiate bench of three judges and/or a judge and lay assessors) (putong chengxu) or simplified procedure (tried by a single judge) (jianyi chengxu). Simplified procedure was introduced into criminal procedure in the 1996 amendments to the Criminal Procedure Law following the experience of the first pilot in the Haidian District Court from 1995 (Zhang 2014). The 1996 amendments confined the use of simplified procedure to publicly prosecuted cases where the possible sentence is less than three years fixed-term imprisonment, criminal detention, control ${ }^{15}$ or a criminal fine where the facts are clear and the evidence is sufficient, and cases filed on complaint or privately initiated prosecutions where there is evidence of a minor crime (Article 174) ${ }^{16}$. In simplified procedure

\footnotetext{
${ }^{15} \mathrm{~A}$ criminal punishment of between three months and two years is served out of prison and subject to the supervision by the local public security agencies.

${ }^{16}$ This definition was later expanded in 2012 to require that the accused does not object to the charges, the applicable law is not disputed, and the accused does not object to the use of simplified procedure (CPL Article 208). Article 209 excludes the use of simplified procedure where the person is deaf, dumb, blind or has a mental disability, where the offense has a major social impact, if it is a joint crime and not all co-accused consent or it is otherwise considered inappropriate.
} 
the procuratorate may decide not to attend the court hearing, and the trial must be completed by the court within twenty days of accepting the case (Articles 175 and 176).

The next major development in simplified procedure that was incorporated into the 2012 amendments to the Criminal Procedure Law flowed from the December 2006 SPP Opinion on Expedited Handling of Minor Criminal Cases according to the Law, to expedite the prosecution stage in minor criminal cases by reducing time limits for procuratorial decision-making. The Opinion provided further detailed specification of the circumstances when simplified procedure could be used. Simplified prosecution may apply where subjective malice is minor, for negligent crimes, neighborhood disputes and where the parties have already reached a civil compensation agreement or other form of reconciliation. It may also be applied where other mitigating factors are present or the offenders, because of age or disability, are eligible for lenient treatment (Article 4). Expedited handling under this Opinion is excluded for crimes related to national security, that are foreign-related or intentional, official crimes, or those that seriously harm national security, the social interest or personal and property rights (Article 5).

The SPP 2006 document provides that a decision on whether to commence prosecution must be made within twenty days of transfer of the case file, or if there is conflict between officials handling the case a maximum of thirty days, with no further extensions permitted (Article 6). Documentation of arrest and prosecution decisions and lists of evidence may be completed in simplified form with an emphasis in the documents on determination of the crime and recommendation on disposal of the case (Article 7). In the prosecution recommendation, the procuratorate should also recommend that the court use simplified procedure in conducting the trial (Article 9), though of course this recommendation is not binding on the court.

The 2012 reforms to the Criminal Procedure Law incorporated provisions from the 2006 Opinion, expanded the jurisdiction to try matters with a single judge using simplified procedure to basic level courts, and removed the restriction concerning maximum punishment (Article 208). A distinction is still drawn between cases where the maximum punishment is three years' imprisonment and more serious offenses in that the former may be tried by a single judge, but the latter must be tried by a collegiate bench (of three) (Article 210). In these cases, the court must conclude the trial within 20 days of accepting the case (Article 214).

Such reforms have sought to speed up processing of criminal trials where the main facts are not in contention, or at least where the defendant does not raise any objections to the evidence and the charges. However, simplified procedure has not substantially reduced the complexity of trial procedure and has not successfully reduced the burden of the high workload on procurators and judges (Liu and Li 2016). The extensive fieldwork of McConville et al. (2011) indicates that simplified procedure has not been universally welcomed by judges or procurators. Their research shows that in practice both judges and prosecutors are reluctant to use simplified procedure because of the short time limits mandated for each stage of the procedure. Many judges indicated they felt that adjudicating a case according to simplified procedure added to their workload by placing much greater responsibility on the individual judge to verify the evidence presented to them. They feared losing the protection afforded by the collective decision-making of a collegiate bench.

Despite this reluctance, expansion to basic level courts in the 2012 amendments to the Criminal Procedure Law increases the attractiveness of simplified procedure for handling minor offenses where evidence is clear and uncontested. Initial research suggests an increase in the number of offenses tried using simplified procedure (Fang 2014).

\section{Criminal reconciliation (xingshi hejie)}

Criminal reconciliation is a relatively new procedure in China. Although its use as a diversionary practice began to flourish only after 2006, the term xingshi hejie (criminal 
reconciliation) had appeared before this time. In 2002, various local courts and procuratorates including the Chaoyang District Procuratorate in Beijing formerly established it as a practice for handling minor assault cases and traffic accidents. Criminal reconciliation functions as an alternative to a criminal trial. It can be presided over by police, prosecutors or judges (Shi 2008; He, T. 2012). It differs from the subsidiary civil action (fudai minshi susong) that is conducted in criminal trials. Subsidiary civil action in criminal trials is handled concurrently with court proceedings where the victim can sue the defendant for material and psychological damage or loss resulting from the defendant's actions. In contrast, criminal reconciliation is a practice aimed at avoiding the cost of a trial and the sentence is tied directly to the willingness of the victim or his/her family to forgive the offender in exchange for an agreed amount of compensation. The end result of a criminal reconciliation agreement between an offender and victim, or their representative, is that the victim is compensated and in return for paying compensation up front the offender is typically given either a suspended sentence or a reduced sentence ( $\mathrm{Ng}$ and He 2016; Trevaskes 2009).. ${ }^{17}$

Throughout the years from 2007 to 2012, both the SPC and SPP issued a series of increasingly detailed provisions that put flesh on the initial bones of the CR's legal framework. It was expanded and included as a special procedure in the 2012 amendments to the CPL. Under this process the offender negotiates for forgiveness from the victim in exchange for an expression of regret and payment of an agreed amount in compensation for losses suffered as a result of the criminal conduct (Article 277). Criminal reconciliation may be conducted at all stages of investigation, prosecution and trial, and will be led by the agency responsible for that stage of the process. If an agreement is reached, this may be taken into account by the police in recommending to the procuratorate that a lenient approach be taken, which might be to prosecute for a lesser offense or to make a decision not to prosecute under Article 142(2). If reconciliation is successful at the investigation or trial stage, the procuratorate may recommend that the court take this into account as a mitigating factor in sentencing (Article 279). Liebman's (2014) study of everyday justice in selected lower level courts in Henan during 2010 indicates widespread use of criminal reconciliation to resolve ordinary criminal matters. His work suggests that reaching an agreement and paying compensation to the victim or their family is the most important factor in the court's determination to impose lenient punishment, or even in having the case discharged (Liebman 2014).

Whilst criminal reconciliation is not confined to minor offenses, it is used primarily in negligent crimes and cases involving criminal infringement upon the person or property (Criminal Law Part 2, Chapters 4 and 5) where the sentence that could be imposed is less than three years imprisonment, control or a fine (Article 278). Over 70 percent of mediated cases involve crimes of intentional injury (where the injuries are minor), stealing and traffic offenses. Like the pilots on expedited handling of minor crimes, one aim of criminal reconciliation is to reach an early resolution and so reduce the amount of time a person who has committed a minor crime spends in pre-trial detention (He 2012).

\section{Non-custodial sentencing}

Courts have a range of sentencing options in punishing minor offenders. They may impose lenient sentences (a discounted punishment in cases including successful reconciliation and payment between the victim and perpetrator), suspended sentences, parole or non-custodial sentences. Whilst sentences may be suspended for serious crimes where the death sentence is imposed, suspended sentences are also a particularly common way for imposing a lenient sentence in respect of minor crimes (Liebman 2014). An initial pilot of increasing the use of non-custodial

\footnotetext{
${ }^{17}$ Criminal reconciliation differs from criminal mediation (xingshi tiaojie) since criminal mediation usually only refers to the post-conviction, pre-sentencing practice of negotiating a suspended death sentence by offering compensation in exchange for agreement from the victim's family to downgrade the sentence from immediate execution to a suspended death sentence.
} 
sentencing through the use of community corrections was begun in Shanghai from 2003. As the initial pilot was deemed successful, the number of pilot sites was expanded until community corrections were finally introduced nationwide when it was written into the Criminal Law in 2011 (Li 2017).

Community corrections may be imposed in a range of circumstances: where a person is sentenced to the criminal punishment of control (Criminal Law Article 38), given a suspended sentence (Criminal Law Article 76), or granted parole (Criminal Law Article 85) and ordered to serve their sentence out of custody. The number of people given community corrections has increased dramatically, from 400,000 in May 2012 (Dui Hua 2013) to 731,000 in November 2014 (Chinanews 2014, Xinhua 2014a). In November 2014, the Deputy Minister of Justice, Zhang Sujun stated that since the beginning of pilot projects in selected locations from 2003, a cumulative total of 2,113,000 people had been punished under the system of community corrections (Chinanews 2014). Whilst community corrections did not act as substitute sanction for laojiao (since for community corrections a person must first be convicted of a criminal offense), including community corrections in the 2011 revisions to the Criminal Law expanded its use nationwide and provided a convenient alternative for punishment of the minor offenses that might previously have been punished by laojiao.

\section{Conditional non-prosecution (fu tiaojian bu qisu)}

Prior to the 2012 reforms to the Criminal Procedure Law, the scope for discretionary nonprosecution decisions by the procuratorate was very small. The procuratorate had discretion to not prosecute where the offense was so minor it did not attract a penalty or where a person could be exempted from punishment (Article 142(2)). Between 2006 and 2010, in only 3 percent of cases sent to the procuratorate, did the procuratorate decide not to prosecute (Chen, G 2013). The 2012 reforms to the Criminal Procedure Law expanded the scope of conditional nonprosecution, primarily for juveniles committing a range of specified minor offenses (primarily against the person and property) that might be punished by up to one year imprisonment, for whom prosecution was suspended for between six months and one year whilst they serve a term of probation (and comply with the conditions set). After the probated person has successfully completed the period of probation, the prosecution issues a decision not to prosecute (CPL Articles 271, 272 and 273). As noted above, availability of probation and conditional nonprosecution usually depends upon reaching a criminal reconciliation agreement and paying compensation to the victim.

\section{Direct prosecution without arrest (bubo zhisu)}

Whilst much consideration has been given to expediting court adjudication, there is a recognized need to reduce the number of people held in detention prior to trial or at least to expedite investigation and prosecution of minor offending. Some of the pilot reforms conducted before the 2014 round have sought to find ways to expedite the investigation stage in minor cases where the evidence is straightforward, as a way of reducing the number of suspects detained during the investigation period, or if they are detained, to reduce the amount of time spent in detention (Li, Zhang and Sun 2014). Moreover, an important reform introduced through the 2012 CPL calls for procuratorate to review pre-trial detention.

One route to achieving this objective is to complete prosecution and trial prior to the thirty-seven day deadline for police detention expiring. This form of prosecution may be used in cases too minor to apply for arrest. Another has been to expand the use of bail and residential surveillance and reduce reliance on arrest and detention during the investigation stage. The police or the procuratorate may grant bail or impose residential surveillance by deciding not to apply for arrest in the former case, or refusing an application for arrest and imposing bail or residential 
surveillance in the latter (Pan 2015).. 18. The SPP 2006 Opinion and the current pilots do not directly engage with this reform, or seek to expand its scope. To date, the procuratorate has issued documents setting out the circumstances where it is appropriate to limit the use of arrest, for example, in the case of juveniles or minor offenses where the parties have reached a compensation and reconciliation agreement (Pan 2015).

\section{Pilot Projects on Expedited Sentencing of Minor Offending 2014-2016}

On 27 June 2014 the NPC Standing Committee authorized the SPC and the SPP to carry out a range of pilots in the Decision on Authorising the SPC and SPP to Conduct Pilots on Expedited Sentencing in Criminal Cases in Some Locations (NPC 2014). The NPC Standing Committee extended the authorization for these pilots for a further two years in Decision on Authorising the SPC and SPP to Conduct Pilots on Plea Agreement for Lenient Punishment in Criminal Cases in Some Locations issued on 3 September 2016 (NPC 2016). One of the primary objectives of this pilot is to overcome deficiencies in simplified procedure and to further expedite and simplify trial procedure (Liu and Li 2016). The pilots starting in 2014 differ from the earlier pilots in terms of scope and applicable trial procedures.

In contrast to the pilots conducted before 2014, which applied to offenses that could be punished with a maximum of three years imprisonment, the pilots authorized by the NPC Decision apply only to offences with a maximum of one year fixed-term imprisonment, criminal detention, control or a criminal fine. The NPC Decision sets out a non-exhaustive list of the types of minor offences that are to be included in these pilots: dangerous driving, traffic offences, theft, fraud, stealing, causing injury, provoking quarrels and causing a disturbance. In addition, to qualify for expedited sentencing, cases must also meet the criteria set out for the use of simplified procedure, that the facts are clear, there is (legally) sufficient evidence, the accused acknowledges guilt, and there are no disputes about the applicable law. The NPC Decision also specifies the locations in which pilots were to be conducted: Beijing, Tianjin, Shanghai, Chongqing, Shenyang, Dalian, Nanjing, Hangzhou, Fuzhou, Xiamen, Jinan, Qingdao, Zhengzhou, Wuhan, Changsha, Guangzhou, Shenzhen and Xi'an.

In August 2014, to implement these pilots the SPC, SPP, Ministry of Public Security and the Ministry of Justice jointly issued a document, Measures on Launching Pilots in Some Areas on Procedures for Expedited Sentencing of Criminal Cases (Joint Measures 2014). Existing provisions of the Criminal Procedure Law apply unless excepted by the Measures, with the basic principle being that the pilots should be carried out consistently with the basic principles of criminal law and procedure, protect the litigation rights of the accused, and ensure judicial justice.

The Measures increased the scope of crimes that are the subject of these pilots to include unlawful detention, drug crimes and bribery (Article 1). They also refined the circumstances in which the crime of provoking quarrels and causing a disturbance can be included within the pilots to situations where the disruptive conduct is in a public place and the circumstances are minor. In addition to meeting the requirements for using simplified procedure (the facts are clear and the evidence sufficient, the defendant confesses to the crime and raises no objection to the charges), additional requirements for expedited sentencing are that the defendant agrees to the procurator's sentencing recommendations (liangxing jianyi.) and agrees (in the form of a written acknowledgement) to the use of expedited sentencing (Articles 2 and 6). Article 5(5) suggests that a compensation agreement should also have been reached with the victim or their family under the criminal reconciliation procedures, but this

\footnotetext{
${ }^{18}$ The Procuratorate exercises legal supervision over criminal procedure (Criminal Procedure Law Article 8) including oversight to ensure lawfulness of coercive measures imposed by the police to deprive a person of their liberty during the investigation phase, such as residential surveillance in a designated location (Article 73), approval of arrest (Article 88) and the need for ongoing custody after arrest (Article 93)
} 
is not a legal requirement. Whilst the procuratorate is responsible for recommending the use of simplified procedure, in the pilots on expedited sentencing, the public security, procuratorate, the accused or their defender can make a request, but the court retains the power to make a final determination on whether to use expedited sentencing procedure (Liu and Li 2016).

As is the case with simplified procedure, a primary focus of these pilots is on setting time limits for eligible cases - on prosecution (Article 8, eight days from transfer of the file) and adjudication (Article 15, seven days from accepting the case). In some areas these pilots have been implemented by including the four justice agencies, each with time limits in performing their respective roles. In Suqian city in Jiangsu, for example, the Intermediate People's Court, Procuratorate, public security and justice agencies established a coordinated mechanism under which the public security agencies were required to transfer the case file to the procuratorate for examination within fifteen days of opening the file, the procuratorate to complete investigation and transfer the file to the court within fifteen days of accepting the file, and the court to complete adjudication within ten days of receiving the file, including completing community investigation (by the Justice Department about appropriateness of a non-custodial sentence) and provision of legal aid (Shen and Yang 2015).

In terms of trial procedure, trial and adjudication are expedited by omitting both court investigation (fating diaocha) and court debate (fating bianlun.), and by use of a standardized form in giving the court's judgment (Shi 2015). The current pilots continue to provide for the accused to make a final statement (in respect of simplified procedure Criminal Procedure Law article 211) (Shi 2015). The current pilots differ from previous practice in that the documents provided to the accused include a sentencing recommendation, which introduces a plea agreement as part of sentencing. The range of agreements within these pilots of plea agreements is confined to setting out the conditions for imposing a mitigated sentence and does not contemplate a wider range of plea agreements such as prosecution on lesser charges (they are already at the minor end of offending) or having some charges dropped altogether (Cao, 2016b). Under the Measures, agreeing to a sentencing recommendation proposed by the procuratorate (which is new to the Chinese system), a guilty plea and successfully reaching a criminal reconciliation agreement operate as mitigating factors in sentencing (Measures Article 13). Although there is an implication that the court will accept and impose the procuratorate's sentencing recommendation, the Measures do not explicitly require this.

In these pilots the Ministry of Justice is involved in two areas: evaluation of the eligibility of an accused for community corrections, and establishing a system of duty lawyers. Within the scope of the pilot, where the procuratorate is considering the possibility that a person may be sentenced to parole or control (and so may be released on a community corrections order), it will ask the justice agency to provide an evaluation about the appropriateness of imposing a non-custodial sentence. The Notice requires the justice agency to complete its evaluation within five days of receiving the written request, and that the investigation be carried out by a minimum of two people including one community corrections official. Based on visits to the accused person's family, school, work unit, local resident committee and police station, as well as to the victim and the victim's family, the report is to include information about the cause and circumstances of the offending, whether the accused shows remorse, the social impact of the offending, whether the accused has a fixed residence and their family and social relationships, to determine whether it is appropriate for the accused to be subject to community corrections (Item 3 ). The issue that remains to be resolved is ensuring that these evaluations are conducted properly and are deemed reliable by the procuratorate and sentencing judge.

The second area of involvement by the justice departments is in arranging for the provision of legal advice to an accused. As a safeguard for the accused in expedited sentencing, the Measures provide for establishment of a system of duty lawyers to be available to provide legal advice to the accused in the watch house (Article 4). On 9 October 2014, the Ministry of 
Justice issued the Notice on Effectively Performing Functions to Do a Good Job of the Work of Pilots of Procedures for Expedited Sentencing of Criminal Cases to mandate establishment of such a system in the pilot sites of legal aid stations (falü yuanzhu gongzuozhan.) at courts and police-operated watch houses (.kanshousuo.) (Ministry of Justice 2014).

Where an accused has not appointed their own legal representative, they may seek the assistance of the duty lawyer to explain the legal consequences of expedited sentencing procedures, to assist in selection of procedures, consult on sentencing recommendations, and generally protect their lawful rights and interests (Item 1 ). In the watch house, the duty lawyer can provide legal education and information about legal aid. Duty lawyer work can be implemented through either or both rotating lawyers or through designating a dedicated duty lawyer. Local justice departments and lawyers' associations are given the responsibility of selecting a cohort of duty lawyers who are experienced in criminal matters and willing to perform the role. Criminal defense lawyers who think that their client might be eligible for expedited sentencing are encouraged to discuss the option with their client, but are not permitted to recommend expedited sentencing to the procuratorate without their client's agreement (Item 2).

However, despite these provisions, a number of resource and structural problems remain with this system. Existing weaknesses in the provision of legal aid to criminally accused have not been resolved and in practice it remains unclear exactly what the role and responsibilities of the duty lawyer to the accused are (Shi 2015). At present it appears that the duty lawyer's role falls far short of representing or defending the accused or advocating on the accused's behalf, and extends merely to educating the accused on the nature of the process and their legal rights and responsibilities. The justice departments have themselves been implicated in punishing criminal defense lawyers whose willingness to defend their clients is seen by the justice department as being too vigorous, or crossing some poorly drawn line of political acceptability. The shortcomings in this particular aspect of legal representation of criminally accused persons are compounded by the already precarious position of criminal defense lawyers in general. The difficulty facing lawyers in representing their clients has been raised above in Part 1 and is revisited in Part 4.

PART 3 Reforming State Responses to Serious Crime

\section{SPC Guidance Instruments}

Criminal justice reform in the area of serious crime is complex and abstruse. Many elements of China's Criminal Law are defined broadly, locking in considerable space for judicial discretion and thus for elements outside the law to shape judges' interpretations and decisions (Trevaskes 2012, 2013a). External sources of influence were particularly at work when the Harmonious Society and Stability Maintenance agendas were at their political peak from 2008 to 2011. A number of controversial death sentences such as the highly public cases of Li Changkui. ${ }^{19}$. and Yao Jiaxin ${ }^{20}$. fed into the Stability Maintenance fever, further reducing

\footnotetext{
${ }^{19}$ Li Changkui was a farmer from Yunnan who in 2011 raped and murdered a girl and killed her three-year old brother. Li was sentenced to death during his first trial, but, because he turned himself in, his death sentence was commuted to death with two-year suspension of sentence. Such decision was appealed by the victims' family and sparked significant public uproar, leading the Yunnan Provincial Court to rehear the case. The court reinstated the original sentence and Li was eventually executed.

${ }^{20}$ In 2010, Yao Jiaxin, a third-year student at the Xi'an School of Music, was sentenced to death and executed after running over a woman with his car and repeatedly stabbed her to death. Believed to be the son of a rich family, Yao's case attracted significant public attention and arising angry sentiments supporting his execution.
} 
public trust in the law (Belkin 2017; Fu 2016a; Miao 2013; Trevaskes 2013a, 2015, 2016; Zhao \& Yuan 2013). After the end of the Stability Maintenance and Harmonious Society era, central Party authorities encouraged the SPC to expand its authority over local courts and to limit local discretion by embedding its own judicial guidance within the wide interpretive space of judicial discretion, in the form of SPC interpretations, policy and model cases. ${ }^{21}$. These initiatives include the case guidance system controlled by the SPC.

The 2013 SPC Judicial Opinion on Building Credibility (SPC 2013) projected three main political aims. These were based on Xi Jinping's first $18^{\text {th }}$. Party Congress statement that justice must be for the people, that judicial authorities must strive to attain judicial fairness in decisionmaking, and that they must improve their public credibility (SPC 2013). The main keyword in this Opinion is standardizing; that is, unifying practice across the nation by reining in local judicial discretion through the use of authoritative guidance instruments and policy produced by the SPC (SPC 2013; Xinhua 2013).

Limiting judicial discretion and standardizing decision-making cannot be considered exclusively a Xi era goal. Indeed, the SPC has been attempting to limit local discretion in serious crime cases since 1999 (Trevaskes 2016b). The most impressive reforms to China's death penalty system came in the Hu Jintao period, on 1 January 2007, when the exclusive authority to review and approve all death sentences was returned to the SPC after three decades in the hands of provincial authorities (Trevaskes 2008; Johnson \& Zimring 2009; Lu et al. 2016). Since this time, SPC authorities have been introducing new ways to limit application of the death penalty at the local level. A new guiding case system established in November 2010 provided the SPC with a more authoritative guidance instrument to standardize decision-making, effectively serving as a new form of judicial interpretation. Guiding cases are not precedent cases, but they function to interpret law by compelling judges to apply the law in a similar way in similar cases (Ahl 2014; Chen X 2016b). The current leadership is accelerating this trend, further corralling local judicial discretion but to date, these cases have not been taken up as widely as the initial SPC hype had suggested they might.

Well over 90 per cent of crimes for which immediate execution is given are drug and homicide offenses (Trevaskes 2012; 2016b). For homicide cases that arise from domestic or neighborhood disputes, SPC efforts to kill fewer, kill cautiously have been developed in the form of guidance mechanisms such as model cases. As part on ongoing efforts by the SPC to severely limit use of the death penalty in local courts, two guiding cases were issued in 2011 and 2012, to clarify the application of a new sentencing principle introduced into the Eighth amendment of the 1997 Criminal Law in 2011. China's unique approach to capital punishment has two types of death sentence: immediate execution (sixing liji zhixing) and the other with a two-year reprieve, known as sihuan. For sihuan, after the two-year period, the sentence is almost invariably downgraded to a life sentence of around eighteen to twenty years. Many judges in local jurisdictions have to routinely deal with the families of murder victims and their threats to petition and protest if the offender is not given a death sentence. In the past, many grieving relatives of murder victims considered the sihuan alternative to execution to be not tough enough, since a life sentence can be further commuted to fifteen years or less in recognition of the criminal's good behavior (Zhao 2012a, 2012b) and a life sentence has traditionally not been close to a full lifetime term (life imprisonment is generally a term of 1520 years).

A new paragraph in Article 50 of the Criminal Law amended in 2011 enables a court to place a restriction on commutation of sentences for violent crimes including murder, rape, robbery, kidnapping, arson, causing explosions, spreading hazardous substances and leading a criminal organization. China's first criminal law-related guiding case, issued in 2011, was Guiding Case No. 4, which clarifies through example the use of this new provision to prevent punitive excess. Guiding Case no. 12 issued in late 2012 works further to justify the use of a suspended

\footnotetext{
${ }^{21}$ For insight into the SPC's guidance mechanisms see Susan Finder's Supreme People's Court Monitor, and Ronald Keith and Zhiqiu Lin (2009).
} 
death sentence and restriction of sentence commutation, even in cases where the offender him/herself does not immediately surrender to police (Chen, X 2016b; Trevaskes 2015). The SPC has been gradually introducing new ways to limit the application of the death penalty in drug transporting cases, not through the use of guiding cases but through a less formal system of issuing sentencing guidelines in the form of SPC conference minutes (Trevaskes 2016b).

\section{Recent Amendments to the Criminal Law to Limit the Death Penalty}

Alongside SPC efforts to reduce the number of executions in China, the NPC passed amendments to the Criminal Law in 2011 (the Eighth Amendment) and 2015 (the Ninth Amendment). Provisions in these two amendments lower the number of capital offenses in the Criminal Law to 46, down from 68 in 2010. The types of crimes taken off the death penalty list in $\mathbf{2 0 1 5}$ are mainly non-violent and economic crimes and they are not commonly crimes for which the death penalty is applied. They include smuggling of weapons and ammunition, manufacturing or possessing nuclear materials or counterfeit currency, raising funds by fraudulent means, organizing prostitution, forcing others into prostitution, obstructing officials from performing their duties, and fabricating rumors to mislead people during wartime. In and of itself, this strategy to remove these types of crimes from the death penalty list will not dramatically affect the number of people executed in China each year. However, leading death penalty scholars such as Zhao Bingzhi see this as a stage-by-stage approach that will gradually whittle down the range of offenses subject to capital punishment to only the most violent crimes. This strategy of a gradual approach is said to allow gradual acceptance of eventual abolition of the death sentence in decades to come (Zhao 2012a, 2012b; Zhao and Yuan 2013).

The death penalty is now applicable to crimes of embezzlement and bribery only when the amount involved is extremely large and where the crime has caused extreme damage to the national and the people's interests (Articles 383 and 386 Criminal Law 2015 Ninth Amendment). The SPP and SPC issued a more official interpretation of punishing these two types of crime on 18 April 2016 by setting the benchmark of extremely large amount at a minimum of three million yuan (SPC-SPP 2016). It also added that the death penalty can be applied in cases involving an amount of 1.5 million yuan or more, when other extremely severe circumstances are involved (Liang 2016). However, a suspended death sentence can be applied where there are mitigating factors, including the willingness of the offender to cooperate during the investigation (China Daily 2016; Dentons 2016).

The 2015 Ninth Amendment to the 1997 Criminal Law introduced a new provision of Life Imprisonment without Possibility of Parole, which is applicable in cases where an offender convicted of embezzlement or bribery is given a death sentence with a two-year reprieve, after the prisoner has served the two-year probation period. The Dui Hua Human Rights journal sees the potential for this amendment to mitigate the public's doubts about giving corrupt officials more lenient treatment and has the potential to clear the way for China to eventually eliminate the death penalty for corruption (Dui Hua Foundation 2015). SPC judge Pei Xianding explains the benefit of the reform: For some defendants, the death penalty is too heavy and a suspended death sentence too light, so we made the new sentence after research and discussion, in a move to ensure punishments will be in line with offenses (Cao 2016a).

\section{Reforms to the Death Penalty Review Process}

The Chinese criminal justice system's notoriety as a mass producer of misjudged cases is historically linked to its flawed death penalty appeal and review process. In the early 1980s the national legislature delegated to provincial courts the authority to review and approve the vast majority of death sentences involving violent and other social-order crimes. This delegation of authority smoothed the way for the three decade long killing spree known as 
Strike Hard. On 1 January 2007, legislative authorities made an historic change to return to the SPC in Beijing the executive authority to decide on the final review and approval process for death penalty cases. It has led to significantly lowering the number of capital punishment executions in China, even though still estimated in the thousands each year.

In 2007, a series of SPC interpretations and other measures specified and explained the procedures in place from 1 January to review all death sentences (Trevaskes 2008). These measures outlined the kinds of death penalty applications that would or would not be accepted for approval by the SPC, including cases that did not reach the accepted standard of proof, that the facts are clear and the evidence is sufficient. Seeking to ensure cautious control over the death penalty review and approval process, these procedures outlined the organization and control of decision-making process in the SPC. A new death penalty building was set up in Beijing with more than 300 new SPC judges reviewing all death sentences across the nation (Dui Hua Foundation 2014). The 2012 CPL put into legal statute SPC measures that were put in place progressively from 2007. Articles 235 to 240 of the 2012 CPL, based on 2007 SPC provisions, feature the following key procedures. First, Article 239 provides for two possible decision scenarios for SPC rejection of a death penalty application. In rejecting the application for execution, the review panel now has the choice to remand the case back to a provincial level court or for the SPC to directly resentence the case. Second, Article 240 provides for mandatory questioning of the defendant by the collegial panel. Judges travel to the provincial detention center to interview defendants on death row only when important facts about the case are unclear from the files. Third, Article 240 gives the defense lawyer the right, upon his or her request, to address the collegial panel and Article 235 gives the right to the SPP to present its opinion of the case to the SPC.

In the period immediately after promulgation of the $2012 \mathrm{CPL}$, legal experts and scholars pointed to a number of problems that make the process less than an ideal guard against overuse of the death penalty as a severe punishment.

- The provisions are silent on how the collegial panel should interview the defendant, that is, face to face or via video-link. From 2007 to 2011, SPC judges were reported to have questioned defendants in 90 per cent of cases (Southern Weekend 2014), but mostly questioning is conducted via video-link and not in person.

- The provisions allow for only limited involvement of the defense attorney.

- The process itself remains as an administrative review, not as an open trial proceeding.

- If a case is rejected and sent back to the provincial people's court, it is unclear under what circumstances the provincial court can directly re-sentence the case to a death sentence with a two-year reprieve and under which circumstances the provincial court should re-hear the case (Jiang 2016; Keith et. al. 2014; Li, Y 2014; Southern Weekend 2016; Wang, L. 2015; Xing 2016).

It is becoming increasingly apparent that the goal of transforming the review from an administrative review to a public court hearing can be achieved only by incremental steps. One positive step in this direction was made on 1 February 2015 with introduction of new SPC measures on hearing defense opinions. The Supreme People's Courts Measures for Hearing Defense Attorney Opinions in Final Review of Death Penalty Cases, effective 1 February 2015, provides for the defense lawyer to access case files from the SPC to review the case. If the lawyer asks for his or her opinion to be heard in person, the judge undertaking the case review must now make arrangements for this (SPC 2015b). Since the 2015 Regulations on allowing lawyers to review all case files came into effect, lawyers and scholars acknowledge that the process of accessing information from the SPC has improved (Southern Weekend 2016). However, according to defense lawyer Zhang $\mathrm{Yu}$, it is difficult to gauge the effect of a lawyer's opinions on the outcome of SPC reviews since lawyers' opinions are not noted in SPC judgment notices (Southern Weekend 2016). 


\section{Preventing Miscarriages of Justice}

Most major commentaries on trial centeredness contrast it with the longstanding mindset of investigation-centeredness, which legal experts argue is a leading cause of miscarriages of justice (Chen and Zhou 2016; Shen 2015; Zhou, B. 2016). Most acts of torture are committed during the investigative stage of criminal proceedings, with the aim of extracting confession from suspects and defenders. Ideological, practical and political reasons explain the phenomenon. These include a strong emphasis on oral confession (kougong) (Jin 2007), the criminal justice system's traditional inclination toward presumption of guilt (youzui tuiding), poor police training, investigative skills and a distorted system of work incentives, political emphasis on stability maintenance, and the justice system's strong inclination toward cracking down on crime and security convictions at all costs. So, while torture is somewhat accepted as a reality characterizing the way in which police conduct investigations, it is not officially condoned (Nesossi 2017a).

The Xi Jinping leadership has been engaged in a battle against wrongful convictions since mid2013. Within months of Xi's ascendency to power, governmental and legal authorities began issuing legal and political documents specifically addressing the causes of judicial errors and abuses of power, identifying avenues for ascertaining individual responsibility, and tackling systemic problems in the justice system. These documents highlight that justice can be achieved only if coordinated by the center of political power (Nesossi 2017a, 2017b).

All reform documents published by the major Chinese organs and widely reported by the official media in 2013 and 2014 focused on two main aspects concerning wrongful convictions. The first, in line with the key debates and the legislative reforms of the previous decade, is the absolute ban on extracting confession through torture during the investigation stage of the criminal trial. In June 2013, the Ministry of Public Security issued the Notice on Further Strengthening and Improving the Work of Implementing the Law in Criminal Matters and Avoiding the Occurrence of Cases of Miscarriages of Justice (MPS 2013) which explicitly calls for improvements in the process of reviewing evidence in criminal trials, according to requirements defined in the 2012 revised Criminal Procedure Law. The second aspect refers more closely to the work of the courts.

On the issue of torture, the 2013 Political-Legal Committee Provisions on Preventing Miscarriage of Justice stress that instances of torture and extracting confession through violent means or other acts of forgery should be punished severely according to the law. These Provisions spell out procedural requirements for courts handling cases where evidence is weak. They provide for excluding evidence obtained through torture or other illegal means (Item 3), strictly examining and cross-examining evidence in court as the basis for conviction (Item 6), and implementing the legal standard of proof (Item 7) (Political-Legal Committee 2013).

Similar points are made in the SPC Opinions on Preventing Miscarriages of Justice, issued on 21 November 2013 (SPC 2013b). These require judges to follow legal procedures strictly, and remind courts of appeal that they are responsible for counterchecking judgments in cases where the evidence is sketchy or the facts are unclear. The document identifies two criteria not included in the 2010 and 2012 legislation to be used to define illegally obtained evidence: when the defendant's confession has been obtained outside a legal place of detention, and when the full confession has not been recorded through an audio-video recording system. The confessions so obtained are considered non voluntary and, as a result, must be excluded. Not without its problems concerning implementation (for example, the adequate use of audio-video recording, access to lawyers during interrogation and other conditions related to interrogation procedures), this reform is nevertheless impressive and builds on previous experiments conducted in police stations and places of pre-trial detention since 2006. 


\section{PART 4 The Continuing Political Character of Criminal Justice}

The criminal justice reforms highlighted in Part 2 and 3 of this paper need to be understood within a broader political context that continues to recognize crime as having an inherent political capacity to threaten the people's democratic dictatorship and to damage or disrupt socialist economic modernization. The way criminal justice institutions work and the criminal legislation is operationalized reflect this underlying political rationale, which is the topic of Part 4.

The priority given to political objectives of criminal justice is explicit in Article 2 of the 1997 Criminal Law, which states:

The tasks of the Criminal Law of the People's Republic of China are to use criminal punishments to fight against all criminal acts in order to defend the security of the State; to defend the political power of the people's dictatorship and socialist system; to protect property owned by the State and the property collectively owned by the working people; to protect the citizens' privately owned property; to protect the citizens' rights of the person and their democratic and other rights; to maintain public order and economical order, and to safeguard the smooth progress of the cause of the socialist revolution and socialist construction.

Here the implication is that regardless of the extent and nature of reform underway, the criminal law system will retain considerable judicial discretion at all stages of the criminal process. This is because judicial discretion and flexibility is politically necessary to fulfill the imperatives of Article 2 of the Criminal Law and allows Party-state guidance or instruction in the process of interpreting law.

A central understanding still inherent in China's criminal justice policy today was embedded in the PRC's first Criminal Law promulgated close to forty years ago in 1979. Flexibility flexible determination and style of criminal procedure and flexible criminal punishment, from conviction to trial and beyond - is central in criminal justice system operations because China's socialist criminal justice needs to remain open to the vicissitudes of economic and political change (Keith 1994). For authorities to successfully adapt to the unpredictable consequences of accelerated economic growth and social change, China's leaders have deemed it necessary to adjust the scales of punishment according to the dictates of the political circumstances of the time. This assumption is based on Maoist utilitarian dialectics (Trevaskes 2016a). ${ }^{22}$. Mao's concept of dividing and breaking up types of criminals into two different categories according to their crime - those who were enemies of the people (serious criminals) and those who were from within the population of what he classed as still among the people (minor criminals) - has enabled the Party to uphold a theory of punishment based on the idea that the majority of offenders, who are minor offenders, should be treated more leniently (until its abolition in 2013, mostly through the system of laojiao) while the minority of (serious) criminals should be treated severely through harsh punishment (Biddulph 2007; Keith 1994).

The majority/minority proportions have always mattered in this dialectic. Thus, the size and composition of the minority in relation to the size and composition of the majority is always subject to modification based on the political circumstances of the day. When particular types of serious crime (robbery, murder, drug crime) have been deemed to seriously threaten the social foundations of reform, the size and makeup of this minority has been expanded to include not only more categories of crime but also to punish these criminal offenses with greater severity. Conversely, when excessively harsh punishment has itself been deemed to be a potential threat to social stability and harmony, the Party has modified policy to expand the share of the so-called minor crime majority (Trevaskes 2016a). We observe this in the recent campaign against lawyers actively working in support of human rights and the spate

${ }^{22}$ This concept is discussed more fully in the accompanying paper in this issue. 
of politically motivated televised confessions of journalists, lawyers and foreign citizens aimed at singling out a "minority" and offer examples of normatively desirable behavior (Sorace 2017). To support the campaign against lawyers, Chinese official media published articles outlining how such lawyers allegedly threaten social stability. In the weeks leading to and following the crackdown in July 2015 (the so-called "709 crackdown"), the People's Daily cast human rights lawyers as a dangerous criminal ring or gang (quanzi.) that has been undermining the social order since 2012 (People's Daily 2015). The articles resurrect Maoist tactics of public shaming to justify repression against alleged dissenters, in so doing labeling them as a criminal gang, which is commonly associated with the serious crime part of the serious crime package.

One reason why, post-Hu Jintao, this dialectical policy has been kept foundational to criminal justice is because social stability remains foundational to China's criminal justice agenda. After Xi Jinping came to power in late 2012, social stability - albeit without the accompanying Hu Jintao era tag of Stability Maintenance - was swiftly re-positioned at the front and center of the Party's central political narrative (Trevaskes 2013b). Xi's hardline language and tactics incorporated two striking features. One is what scholar Qian Gang (2014) calls deep red Maoist discourse, including terms such as the mass line (qunzhong luxian), which is still in routine use in SPC discourse today (c.f SPC 2015c). In 2013, Xi began articulating a renewed role for central Party and justice authorities in Beijing in combatting the enemies of China's economic development and social order. And in early January 2014 he declared that politicallegal organs are the dagger-handle of the Party (Xinhua 2014b), deploying the Maoist daggerhandle term that conveys a battle is at hand. Indeed, in defending the social and political stability that the Party identifies as necessary for smooth economic reform, political-legal agencies have been required to combat targets of punishment and containment on a number of fronts including corruption, dissent and terrorism. Also intrinsic to this move is the role of these agencies in combatting the deeply entrenched public distrust of the law, which is the product of not just Hu Jintao's Stability Maintenance agenda but decades of local government abuse of power and local judicial protectionism.

Fu and Cullen (2011) claim that in China a high voltage line runs between permissible and prohibited legal practice, and crossing this line results in punishment and repression. The line is shifted over time, drawn differently in dissimilar cases and by various levels of government, according to the perceived political importance of the relevant case at a particular time. Sometimes it is not drawn at all as it is more strategic to leave it blurred. The coercive tools used against weiquan rights lawyers, ${ }^{23}$. for instance, involve depriving them of their fundamental rights through both legal and extra-legal means. The key measures taken against weiquan lawyers and other activists include both direct and indirect actions. The former involves actions by the authorities from the Ministry of Public Security, the local public security bureaus and, in particular, the so-called domestic security squad (guobao), the Ministry of State Security and its police and local governmental officials. Indirect actions, involves measures aimed at restraining or putting pressure upon weiquan lawyers through their employers, landowners, family, friends and neighborhood; legal methods that rely on extra-legal norms and procedures; extra-legal measures, including punitive responses that are beyond legal review and the legality of which is dubious; severe action in the form of physical assault, imprisonment, and/or the loss of material resources for either the lawyers themselves or their relatives and friends; along with other responses (China Human Rights Lawyers Concern Group 2016.; Human Rights Watch, 2015; Hernandez 2016; CECC Annual Report 2016; Leavenwork 2016; Wen 2016). Violence, harassment and intimidation of the individuals or their families are very often the corollary to such measures and frequently go unreported. Some of these acts may be inflicted only once, others more often (Pils 2014; Trevaskes and Nesossi 2016; 2017). We find with this dialectical policy of expanding the minority (of enemies of the state) that not only are the categories of crime expanded to

\footnotetext{
${ }^{23}$ As noted by Pils (2015) and Liu and Halliday (2016), the expression weiquan lawyers does not indicate a monolithic group, rather a fairly heterogeneous one representing different personal approaches to rights, justice and politics.
} 
include new targeted crimes, but also that greater severity can be given in punishing these targeted offenses. We see this currently in the Xi leadership's campaign against lawyers. One of the charges used extensively against the lawyers - used in the case involving the prominent weiquan lawyer Pu Zhiqiang tried in December 2015 - is "picking quarrels and provoking troubles" as defined in Article 293 of the 1997 Criminal Law. The 2011 revision of the Criminal Law altered the maximum sentence for Article 293 from five to ten years for gathering others on numerous occasions to commit the crime (Chen X, 2016a).

The problem with trial-centeredness as a rhetorical plea for preventing abuse of power: the extraction of confession through torture

Condemning the practice of torture has become a regular feature of the PRC's criminal justice discourse since the 1990s (Nesossi 2017a), following the ratification of the International Convention against Torture (CAT), ${ }^{24}$ and the increased discussions concerning human rights, ${ }^{25}$ the amendment of the 1979 Criminal Procedure Law and the possible signature and ratification of the International Covenant of Civil and Political Rights (ICCPR).. ${ }^{26}$. Over these decades, despite the repeated pleas from Party, SPP, SPC and Ministry of Public Security authorities in Beijing to halt the routine abuse of powers, structural changes that would dramatically decrease the incidence of interrogational torture have not been forthcoming (Human Rights Watch 2015).

One of the key related and widely debated issues is the law and practice of the exclusion of illegally obtained evidence. When the 1979 CPL was amended in 1996, legislators merely reiterated the provision on the prohibition of torture already contained in the 1979 version of the law, without including any enforceable rules on the admissibility of evidence, particularly illegally obtained evidence. Article 43 of the $1996 \mathrm{CPL}$, regarding the collection of evidence was the same as Article 32 in the 1979 law and consisted in a declaration that judges, procuratorates and investigators must not use unlawful means to collect evidence. It prohibited forced confessions and the collection of illegal evidence by threat, enticement, deceit or other unlawful means (see also Articles 247-248 of the 1997 Criminal Law similarly prohibiting the extraction of confession through torture). However, the law ignored the questions of what constitutes illegal evidence and how it should be excluded. Further, it did not expressly mention the use of confession extracted through torture as evidence before the court; and, it did not establish legal remedies that could provide avenues for redress, or specific enforcement measures. This meant that judges had little alternative other than to ignore arguments made by the defense regarding the illegality of evidence and even if they wanted to exclude evidence they could not find any support in the legislation. Upon receiving a request for excluding evidence, the court generally did not conduct an independent investigation on the case and the way the evidence had been obtained, but tended to accept passively the assurance of the investigative authorities that there had not been any act of torture (Qiu 2008).

Following years of debates, the concept of exclusion (paichu) was formally introduced in a Chinese legislative document in 2001, in the aftermath of the notorious case of wrongful conviction of Du Peiwu, ${ }^{27}$. with the issuing of the Notice on Strictly Prohibiting the Use of

\footnotetext{
${ }^{24}$ The PRC ratified the CAT in 1988. Since then, it has been subject to five reviews by the UN Committee Against Torture $(1990,1996,2000,2008,2015)$ and has been visited by the Special Rapporteur on Torture Manfred Nowak in 2005.

${ }^{25}$ The PRC published its first White Paper on Human Rights in 1991.

${ }^{26}$ The PRC signed the ICCPR in 1997. It has yet to ratify it.

${ }^{27} \mathrm{Du}$, a former police officer, was wrongly convicted of the murder of his wife and a policeman, and the sentence was based on his false confession extracted through torture. During his trial, he claimed to have been beaten, hung with handcuffed wrists and shocked with a cattle prod. In November 2000, Du was released after a group of car thieves confessed to the murders.
} 
Confession Extracted by Torture as the Basis for Conviction by the SPP. ${ }^{28}$. The Notice requested the procuratorate to resolutely exclude confessions obtained through coercive or other unlawful means. Consistent with Article 265 of the 1999 SPP Rules on Criminal Procedure of the People's Procuratorate ${ }^{29}$ and Article 61 of the 1998 SPC Interpretations on the Implementation of the Criminal Procedure Law $^{30}$. the exclusion of evidence would have led to the reinvestigation of the case.

At the end of May 2010, in the aftermath of another case of wrongful conviction, the Zhao Zuohai case, ${ }^{31}$ the SPC, the SPP, the Ministry of Public Security, the Ministry of State Security and the Ministry of Justice jointly issued two new regulations: the Regulations on Several Issues concerning Examination and Evaluation of Evidence in Capital Cases ${ }^{32}$ and the Regulations on Several Issues concerning the Exclusion of Illegally Obtained Evidence in Criminal Cases ${ }^{33}$. (hereafter Evidence Exclusion Regulations). These two documents represent the first attempt to establish exclusionary rules for illegally obtained evidence - with the word illegal referring to the procedures used by investigators to produce evidence - and to identify the scope and procedures for exclusion.

Two years after the issuing of the Evidence Exclusion Regulations, Chinese legislators issued a revised Criminal Procedure Law, including provisions concerning the exclusion of illegally obtained evidence (Article 54), further explained in the three interpretation documents issued respectively by the SPC, SPP and Ministry of Public Security at the end of 2012. ${ }^{34}$. As mentioned above, in November 2013, the SPC issued the Regulations on Miscarriages of Justice ${ }^{35}$. offering further details regarding the issue of extraction of confession through torture and enlarging the type of practices that should be considered illegal.

Notwithstanding legislation providing for the exclusion of illegally obtained evidence, Chinese scholars' field research highlights a number of contentious issues that continue to hinder the application of exclusionary rules in individual cases. First are problems specifically concerned with the legislation prohibiting torture and regulating the exclusion of illegally obtained evidence: the CPL contains numerous ambiguities and leaves considerable discretion to

\footnotetext{
${ }^{28}$ In Chinese, Guanyu Yanjin Jiang Xingxun Bigong Jiangqu De Fanzui Xianyiren Gongshu Zuowei Ding'an Yiju De Tongzhi (2001).

${ }^{29}$ In Chinese, Renmin Jianchayuan Xingshi Susong Guize.

${ }^{30}$ In Chinese, Guanyu Zhixing Zhonghua Renmin Gongheguo Xingshi Susong Fa Ruogan Wenti De Jieshi.

${ }^{31}$ After spending in prison eleven of the twenty-nine years of which he was sentenced, Zhao Zuohai was exonerated for a crime he never committed. Similar to She Xianglin's wife, Zhao's alleged murder victim Zhao Zhanshang, returned from the dead to their home village to claim social welfare benefits. Years earlier, the couple had argued violently shortly before Zhao Zhanshang disappeared. A headless decomposed body was found in a well near their village, leading police to suspect Zhao Zuohai had murdered Zhao Zhanshang and to arrest him. Forced to confess to a murder he never committed, Zhao Zuohai was sentenced to death - a sentence that the court later commuted to a twenty-nine-year prison term (Chao et al. 2010; Tong and Liu 2010). Zhao was compensated RMB770,000 (approximately $\$ 115,000$ ) ('Zhao Zuohai gains 120,000 yuan extra. 19 May 2010, http://www.china.org.cn/china/201005/19/content_20074842.htm2010).

${ }^{32}$ In Chinese, Guanyu Ban'an Sixing Anjian Shencha Banduan Zhengju Ruogan Wenti De Guiding.

${ }^{33}$ In Chinese, Guanyu Ban'an Xingshi Anjian Paichu Feifa Zhengju Ruogan Wenti De Guiding.

${ }^{34}$ SPC (2012); for SPP Interpretations see

http://www.spp.gov.cn/sscx/201502/t20150217 91462.shtml;

http://www.spp.gov.cn/flfg/gfwj/201212/t20121228 5219.shtml; for MPS Provisions see http://www.mps.gov.cn/n2254314/n2254409/n2254443/n2254452/c3708286/content.htm I.

${ }^{35}$ In Chinese, Guanyu Jianli Jianquan Fangfan Xingshi Yuanjia Cuo'an Gongzuo Jizhi De Yijian.
} 
individual judges. Torture is not specifically defined, so aside from ways that clearly use physical violence, judges find it difficult to determine that coercive practices such as sleep deprivation, for example, constitute torture and should thus be considered illegal according to the 2010 Two Regulations and the 2012 Criminal Procedure Law (Guo Z, 2015). Moreover, the 2012 CPL does not provide details of precisely what constitutes enticement and deceit to distinguish these two styles from lawful investigative means. Nor does it solve the fruit of the poisonous tree dilemma, since it does not clarify whether confessions that one person gives after those provided illegally should be excluded, and whether the evidence obtained from illegal confessions should be excluded (Yang and Chen 2015). Finally, the legislation is still focused on excluding oral confession, while there is still uncertainty about the weight of physical and documentary evidence and its relationship to the confession (Chen and Guo 2014).

Second is lack of clarity in relation to the procedures to be adopted to exclude evidence. While both the Evidence Exclusion Regulations and the 2012 CPL provide for a pre-trial hearing during which the court may decide on the legality of evidence (Lewis 2011), today judges tend to decide about evidence during the trial of first instance and, at times, during appeals. The requirements for initiating exclusionary procedures are fairly complex and the standards to prove that torture has been committed are set extremely high (Wang S 2015). There are no established remedial actions that the defendants can pursue when the judge rejects their application for exclusion as the law is silent on the matter, and it remains unclear what types of procedures the judge should adopt to dismiss an application for exclusion.

Third, the role of the defense remains fairly weak despite the fact that the CPL 2012 allows for defendants' earlier access to defense (in comparison to the 1996 version of the law) (Liang and He 2014; Liang et. al 2016; Liu and Halliday 2016). This is in part because lawyers are still not permitted to be present during interrogation and the only evidence lawyers are generally able to collect to substantiate an allegation of torture is the victim's statement, physical evidence on the victim's body and any available medical report... ${ }^{36}$.

Fourth, institutional relationships among the public security, the procuratorate and the courts (known collectively as the gongjianfa) remain difficult, with the public security being the most powerful agency among the three (Liu and Halliday 2011; 2016). Excluding evidence means reversing decisions taken by police, prosecutors or judges concerning offenders. It means seeking responsibility among the investigative authorities and ascertaining the failures of the prosecutorial authorities in filing cases. These processes are particularly problematic in a system where the courts remain the weakest institutional parties in comparison to the police and the procuratorate.

\section{PART 5: Evaluating Reform in the Context of China's Political-Legal Culture}

From the discussion above, we find that the current yifa zhiguo platform is to perform the same type of political role that the Harmonious Society agenda performed: as a catch-all discursive framework and reference point through which to push through difficult institutional reforms. Political platforms such as yifa zhiguo are a rhetorical touchstone through which reform can be rationalized and justified in political terms, thus making it more difficult for opponents to argue against. That the Party has chosen the catchphrase Governing the Nation According to the Law through which to articulate its current round of changes does not require us as criminal justice scholars to evaluate these reforms through the conceptual prism of a thick or thin rule of law.

\footnotetext{
${ }^{36}$ As noted in Nesossi (2012), lawyers do not generally seek the support of doctors or psychologists in assessing clients who claim to have been tortured. According to interviews with lawyers, they distrust doctors and psychologists because, as state employees, they are deemed unable to conduct an independent and reliable assessment (Nesossi 2012, 191).
} 
We acknowledge that some observers, particularly outside China, may interpret this slogan through the legal lens with which they are familiar, i.e., a rule-of-law concept. However, we see that in this phrase rule refers to that of the nation, not that of law; in accord with the law refers to law as the overarching regulatory system created, used and enforced by the Partystate as it rules the nation.

We also acknowledge in this mix the political ambition of the yifa zhiguo reforms, that is, the immense credibility-deficit that these reforms are attempting to fill. While most of these judicial reforms are indeed recognized as positive and welcomed by legal experts within and outside China, most scholars agree that what is packaged under the yifa zhiguo rhetorical banner does not necessarily signify deep structural reform (cf. Clarke 2015; Minzner 2015; Li, L. 2015a; Pils 2015). Indeed, some would argue that the reforms described above remain to be reforms on paper since most (especially in the arena of minor crime) are in their initial stage of implementation. Below, we outline some of the limitations of these reforms in relation to minor and serious crime.

\section{Limits of minor crime pilot programs}

It is too early to evaluate the full impact of pilot trials on the handling of minor offending, but preliminary reports provide some indication. Of course, whatever the actual outcomes, reports will deem the trials successful (as reports on pilots always do). One indication that central levels have determined to persist with these reforms is that the NPC Standing Committee authorized new two year trials for expedited handling and reduced sentencing where a person acknowledges guilt and accepts the procuratorate's sentencing recommendation from 3 September 2016 (Decision on Authorising the SPC and SPP to Conduct Pilots on Plea Agreement for Lenient Punishment in Criminal Cases in Some Locations).

An interim report issued in August 2015 reported that in the trial sites, for cases where a sentence of less than one year imprisonment was imposed, expedited sentencing had been used in 30.7 percent of eligible cases, which comprised 12.8 percent of all criminal cases. The average time for the procuratorate to investigate and transfer the matter to court using the expedited processes reduced dramatically from twenty days to nearly six (5.7) days, and in 94 percent of cases the court trial was completed within ten days. At 2.1 percent, the appeal rate was 2 percent lower than that for simplified procedure (Liu and Li 2016, 150-151). Another report mostly concurs with these figures, and provides some more detail. In the trial sites, the share of cases handled using expedited sentencing as compared to the total of criminal cases ranged from 16 percent at the top, to .09 percent at the bottom, with the average around 3 percent (Fu and Yu 2016, 1075-1077). It is a smaller number than the other statistics advise. This report also suggests that expedited sentencing has been concentrated on dangerous driving, theft and intentional injury cases, which comprise 77 percent of all cases. It also points to the low uptake of duty lawyers in expedited sentencing cases, with lawyers involved in only 6.2 percent of cases (compared to 13 percent in all criminal cases). For those who expressed unwillingness to use a lawyer, reasons included lawyers were no use, were not needed, could not give relevant advice or assistance, could not be trusted, or that not using a lawyer was a way of expressing a correct attitude that would contribute to obtaining a mitigated sentence (Fu and Yu 2016). Their skepticism is not without foundation as the task and responsibility of duty lawyers remains undefined. In fact it is not clear that duty lawyers have a responsibility to represent the interests of their client, as we might assume. Current regulations suggest that they are merely responsible to inform the detainee about expedited procedures, educate them about their legal responsibilities or to perform other tasks like notifying family members of their detention. Other reports suggest that the system of duty lawyers lacks adequate definition and resourcing, so further reforms will be needed to make the system functional.

In evaluating these reforms it is also important to look outside the parameters set by the reforms themselves to consider what they do not address. The current round of reforms 
focuses on creating efficiencies primarily through reduced time limits for different stages of the criminal process, but it does not address some of the most significant shortcomings in the system that hinder just administration. Expedited sentencing is conditioned upon an acknowledgement of guilt, which in turn makes lenient sentencing possible. Significantly, these reforms do not address the circumstances in which an acknowledgement of guilt is obtained or the motivations for acknowledging guilt. The current round of reforms does not put in place any institutional mechanism to check whether the acknowledgement of guilt is true or reliable when the person confessing may not have committed either that offense, or any offense, and makes a confession merely to move through the system more quickly.

As discussed above, institutional incentives to obtain a confession remain, including the continuing reliance on confession to ground a prosecution and the expedited handling of cases being dependent upon obtaining a confession. The circumstances of initial detention and police interrogation, the limited number of people released on bail, and lack of availability of legal representation focused on protection of the rights and interests of the accused (as opposed to education about the legal process and obligations to cooperate with police investigation) provide the institutional setting that encourages a person to confess. An early acknowledgement of guilt, for example, is not made on the basis of an informed decision about the strength of the prosecution's evidence.

A further incentive to acknowledge guilt is the possibility of obtaining a more lenient punishment and being processed through the system more quickly. In China, a very large proportion of people already admit guilt, which in theory is taken into account as a mitigating factor. Refusing to admit guilt is often seen as resistance, warranting harsher punishment (Dobinson 2013). So, it remains to be seen whether the current round of trials will produce additional reductions in sentences over and above those that would have otherwise been obtained.

\section{The limitations of death penalty reforms}

We discussed above the impressive efforts by the NPC and SPC to limit application of the death penalty. Scholars outside China, however, argue that the 2012 CPL changes fall well short of being comprehensive (Jiang 2016; Keith and Hou 2014; Li, Y. 2014; Southern Weekend 2016). Most importantly, the provisions do not provide for mandatory oral proceedings in which both parties and witnesses can be questioned.

These views are shared by a number of scholars in China who see a trial-orientated approach as necessary to address both procedural and substantive issues that emerge from the collegiate panel's investigations (Li 2014, 26). One of the main criticisms of the current administrative review style is that it is conducted in a way that is not conducive to fact-finding and therefore has limited capacity identify errors or illegalities (Li, F. 2014, 26). According to Article 347 of the SPC's 2012 Judicial Interpretations that accompany the 2012 CPL, apart from the interview with the defendant, the only information on which the collegiate panel can base its decision is the case file sent up from the provincial court. The file contains basic information about the defendant and victim; the defendant's prior criminal records if any, the investigative circumstances of the case; a summary of the adjudication process at first instance including the opinions of the defendant and prosecution; if appealed, the grounds of the appeal and opinions of the procuratorate including the case facts; and other matters including sentencing of co-defendants in the case of joint crimes. Given that the vast bulk of information given to the SPC derives from the appeal court that sentenced the offender to death, it is surely conceivable that the appellate court could withhold from the file it prepares for the SPC documents or other evidentiary materials that are not conducive to upholding the sentence that the appellate court itself imposed.

Post-2013, prominent legal scholars and lawyers within China including Chen Guangzhong and Chen Youxi have increasingly called for improvements to the procedures that would transform the process from a paper-based case dossier examination into a full and credible 
oral proceeding (see Wang, L. 2015). Some scholars call for a full-blown third instance trial; others argue against this, maintaining that since the SPC receives thousands of cases for death penalty review each year, holding an open trial for each is unworkable. Yet others argue for a comprise position: a third instance trial limited to only those cases in which the SPC requires clarification, or has doubts about the substantive findings or procedural propriety of the first instance or appeal trial (Xing 2016).

What the 2012 CPL and its accompanying 2012 SPC Interpretations do not provide is a set of unified standards that SPC judges should use to ensure equity across the SPC tribunals and panels. As scholar Zhang Yu has noted, the original intention of death sentence review and approval is to unify the standards. This problem is still not resolved (cited in Southern Weekend 2016). At least one SPC deputy president recognizes the need to regularize decision-making in the SPC. He admitted to a journalist in 2016 "It is necessary to establish a system of integration at least within the Supreme People's Court ...The original intention of death sentence review and approval is to unify the standards. But this problem is still not resolved (cited in Southern Weekend 2016)".

While the post-2007 approval and review process in the hands of the SPC has no doubt saved many thousands from execution, the process remains flawed, inconsistent and open to the vicissitudes of political change. It is difficult to understand the legal reasoning used by SPC judges who reject some sentences while upholding the sentence of immediate execution for others. ${ }^{37}$. Most importantly, death penalty decision-making in China remains highly amorphous since the basic death penalty provisions in the Criminal Law remain vague. Article 48(1) states that the death penalty should be applied only to criminals who have committed extremely serious crimes. And without further detail it states: If the immediate execution of a criminal punishable by death is not deemed necessary, a two-year suspension of execution may be pronounced simultaneously with the imposition of the death sentence. As the law provides no indication, what constitutes extremely serious crime is the most contested issue in death penalty politics and debate in China (Trevaskes 2012, 2015). Since the Party-state injects national policy directives relating to capital sentencing into this wide discretionary space, judges are highly dependent on both national policy and on vague sentencing principles in the Criminal Law, specifically in relation to drug crime. This means that at both first and second instance judges have broad discretionary space to decide who to execute and to whom to give a suspended sentence (Trevaskes 2012, 2013, 2016c). Impressive SPC sentencing guidelines for less serious crime are a very welcome advancement, but detailed guidelines on death penalty sentencing are not forthcoming.

\section{Conclusion}

The main focus of the review article has been on how the yifa zhiguo platform reflects criminal justice law and policy reforms Xi Jinping's yifa zhiguo is indeed helping to reframe criminal justice reform to correspond with the Party's broad political governance goals, which include rebalancing political-legal control and recentralizing power, standardizing decision-making, and strengthening opportunities for judicial fairness and efficiency in the mainstream of the system. This highly legalist and instrumentalist vision of law is seeking to build the legitimacy and credibility of the political-legal regime and to more effectively control dissent and crime through criminal law, to sustain Party supremacy and social stability. At the same time, it has preserved a highly politicized distinction between the mainstream of the system and legal and extra-legal repression of groups such as rights lawyers characterized as being opposed to the Party-state.

Using a political platform as a rhetorical lever for reform makes the platform vulnerable to the political winds of change with the advent of a new, differently minded Party leader, as

\footnotetext{
${ }^{37}$ For instance, see debate over the death sentence given to Jia Jinglong in late 2016 (Mai 2016; Zhao, Y. 2016).
} 
the rhetorical shift between Hu and Xi illustrates. The law reform initiatives under Xi have not drawn overwhelming admiration and praise internationally, perhaps largely because they were launched at the same time as the unprecedented crackdown on lawyers and the employment of legally dubious tactics to suppress dissent on a wide scale. These approaches to criminal justice, simultaneous yet diametrically opposed to each other in terms of jurisprudence, call into question both the extent and the substantive content of the concepts of justice and fairness at the forefront of the current Governing the Nation According to the Law platform. These approaches, and the concepts of justice and fairness that they draw from and project, were designed to convince a skeptical Chinese population and international audience that national standards of fairness and justice can be improved towards international standards. The discussion of reforms in the areas of minor and serious crime illustrate the tensions inherent in implementing reforms in the name of justice, fairness and efficiency, without entertaining the prospect that a more comprehensive overhaul of the system might be required to achieve them. In fact where reforms are driven primarily by efficiency, which many of the reforms discussed in the paper are, they may be in tension with justice and fairness, especially if considered from the point of view of the person subjected to criminal investigation, prosecution and conviction.

We might go further to argue that the ideological premise behind the current yifa zhiguo platform is problematic in its claim that despite the presence of a minority of corrupt individuals, the Chinese Party-state itself is an intrinsically moral institution whose interests inherently represent the interests of the people. This so called harmony of interests between state and society infers there is no need for an entity outside the Party, such as a system of law that protects the nation and its people against the power of the Party (Rosenzweig 2017).

This political logic works against those who find themselves outside, and penalized by, statesanctioned values and understandings of justice. We see this working against lawyers caught up in unprecedented attacks upon them in 2015 and 2016. Party authorities have moved strongly to suppress the activities of weiquan rights-protection lawyers, labor activists and NGOs, taking into custody more than 250 lawyers and professional legal staff or placing them under residential surveillance at a fixed location without access to their own lawyers. While some were released within days or months according to the terms of the law, others have been charged with the crime of picking quarrels and provoking troubles, inciting subversion of state power or subverting state power (China Human Rights Lawyers Concern Group 2016; Hernandez 2016). Their example illustrates the potential danger that the yifa zhiguo banner can create in denying the nation's people protection against the power of the Party. Governing the nation in accord with law is, after all, governance in accord with Party-state sanctioned values and Party understandings of justice.

\section{References}

Ahl, Björn. 2014. Retaining judicial professionalism: the new guiding cases mechanism of the Supreme People's Court. The China Quarterly 217: 121-139.

Belkin, Ira. 2017. Justice in the PRC. How the Chinese Communist Party's has struggled with managing public opinion and the administration of criminal justice in the internet age. In Justice: The China Experience, ed. Flora Sapio, Susan Trevaskes, Sarah Biddulph and Elisa Nesossi, 195-228. Cambridge UK: Cambridge University Press.

Benney, Johnathan. 2013. Defending Rights in Contemporary China. London and New York: Routledge.

Biddulph, Sarah. 2007. Legal Reform and Administrative Detention Powers in China. Cambridge: Cambridge University Press. 
Biddulph, Sarah. 2015. The Stability Imperative: Human Rights and Law in China. Vancouver: UBC Press.

Biddulph, Sarah. 2016. What to make of the abolition of re-education through labour? In Legal Reforms and the Deprivation of Liberty in Contemporary China, ed. Elisa Nesossi, Sarah Biddulph, Flora Sapio and Susan Trevaskes, 23-42. Abingdon and New York: Routledge.

Biddulph, Sarah. 2017. Justice at the margins: notions of justice in the punishment of prostitution. In Justice: The China Experience, ed. Flora Sapio, Susan Trevaskes, Sarah Biddulph and Elisa Nesossi, 312-355. Cambridge UK: Cambridge University Press.

Biddulph, Sarah. Forthcoming 2017. Punishments in the post re-education through labour world: questions about minor crime in China. In Chinese Legal Reform and the Global Legal Order: Adoption and Adaptation, ed. Yun Zhao and Michael Ng. Cambridge UK: Cambridge University Press.

Biddulph, Sarah, and Chuanyu Xie. 2011. Regulating drug dependency in China: the 2008 Drug Rehabilitation Law. British Journal of Criminology: 1-19.

Brødsgaard, Kjeld Erik and Nis Grünberg. 2014. The fourth plenum of the CPC makes an important decision on law reform in China. The Copenhagen Journal of Asian Studies 32(2): 122-130.

Cao, Liqun, Ivan Y Sun and Bill Hebenton. ed. 2013. The Routledge Handbook of Chinese Criminology. London and New York: Routledge

Cao, Yin. 2016a. Life term, no parole given now for graft. China Daily. 19 April, <http://www.chinadaily.com.cn/china/2016-04/19/content_24646800.htm>

Cao, Yin. 2016b. Top court proposes test of plea bargaining. China Daily, 30 August, <http://europe.chinadaily.com.cn/china/2016-08/30/content_26637683.htm>

Chen, Albert H.Y. 2016. China's long march towards rule of law or China's turn against the law? The Chinese Journal of Comparative Law 4: 1-35.

Chen, Guangzhong. 2013. Issues in the reform of China's public prosecution system- against the backdrop of new revisions to the Criminal Procedure Law. In Comparative Perspectives on Criminal Justice in China, ed.Mike McConville and Eva Pils, 153-171. Elgaronline: Edward Elgar.

Chen, Guangzhong and Guo Zhiyuan. 2014. Feifa zhengju paichu guize shishi ruogan wenti yanjiu [Research on the various problems concerning the application of exclusionary rules]. Faxue zazhi [Legal Science Magazine] 9: 1-16

Chen Guangzhong et.al. 2016. 'Yishenpan wei zhongxin' yu jiancha gongzuo ['Making the trial central to the process' and prosecution work]. Zhongguo faxuehui [China Law Society], 16 February, <https://www.chinalaw.org.cn/Column/Column_View.aspx?ColumnID=956\&InfolD=18581 $\geq$

Chen, Guoqiang and Zhou Ying. 2016.'Yishenpan wei zhongxin' yu jiancha gongzuo ['Making the trial central to the process' and prosecution work]. Xingshi sifa zhinan [Directions in Criminal Justice]. 14 October, <http://www.jcrb.com/procuratorate/theories/practice/201610/t20161014_1660326.html>

Chen, Jianfu. 2016. Efforts towards procedural justice in post-mao China. In China's Socialist Rule of Law Reforms Under Xi Jinping, ed. John Garrick and Yan Chang Benne, 94-108. London and New York: Routledge. 
Chen, Ruihua. 2017. 'Shenpan zhongxinzhuyi gaige' de lilun fansi [Theoretical reflections on 'trial centeredness reform']. Suzhou daxue xuebao (zhexue shehui kexue ban) [Academic Journal of Suzhou University (Philosophy and Social Science)] 1: 34-43.

Chen, Weidong. 2016a. Dangqian sifa gaige de tedian yu nandian [The characteristics and difficulties with current judicial reform]. Hunan shehui kexue [Hunan Social Sciences] 2: 5256.

Chen, Weidong. 2016b. 'Yishenpan wei zhongxin': jieshi, shixian yu fazhan ['Making the trial central to the process': interpretation, realisation and development]. Dangdai faxue [Contemporary Legal Studies] 4: 14-21.

Chen, Weidong. 2016c. ' Yishenpan wei zhongxin': dangdai Zhongguo xingshi sifa gaige de qidian ['Making the trial central to the process': the starting point of criminal justice reform in contemporary China] Faxuejia [Jurist] 4: 1-15.

Chen, Xi. 2012. Social Protest and Contentious Authoritarianism in China. New York: Cambridge University Press.

Chen, Xingliang. 2016a. Image of crime of picking quarrels and provoking trouble in legal dogmatics: centering on creating disturbances. China Legal Science 4: 121-144.

Chen, Xingliang. 2016b. Guiding cases for China's death penalty: analysis and reflection. In China's Death Penalty in Transition: Theory, Policy, Practice and Reform ed. Bin Liang and Hong Lu, 187-213. New York: Columbia University Press.

Cheng, Li. 2006. Think national, blame local: central-provincial dynamics in the Hu era. China Leadership Monitor, 17:

$<$ http://www.hoover.org/research/think-national-blame-local-central-provincial-dynamicshu-era>

Clarke, Donald. 2015. China's legal system and the fourth plenum. Asia Policy 20: 10-16.

China Daily. 2016. Criteria clarified for capital punishment in graft cases. Xinhua, 18 April, <http://www.china.org.cn/china/2016-04/18/content_38267461.htm>

China Law Translate. 2015. Opinion of the supreme people's court on deepening reform of the people's courts comprehensively: outline of the fourth five-year reform of the people's courts (2014-2018). 25 February, <http://chinalawtranslate.com/court-reformplan/?lang=en>

Chinanews. 2014. Sifabu fubuzhang: shequ jiaozheng fa cao'an songshengao zheng wanshan [Deputy minister of justice: the draft community corrections law for examination has been completed]. Chinanews.com. 5 November.

China Human Rights Lawyers Concern Group. 2016. ['709 Crackdown'] Latest data and development of cases as of 18:00. 23 August, <http://www.chrlawyers.hk/en/content/\%E2\%80\%98709-crackdown\%E2\%80\%99-latestdata-and-development-cases-1800-23-august-2016>

CECC. 2016. Congressional-Executive Commission On China. Annual Report 2016 $<$ https://www.cecc.gov/>

Corne, Peter Howard. 2002. Creation and application of law in the PRC. The American Journal of Comparative Law 50(2): 369-443. 
Dai, Yuzhong. 2010. The pursuit of criminal justice. In China's Journey Toward the Rule of Law: Legal Reform, 1978-2008, ed. Cai Dingjian and Wang Chenguang, 155-197. Leiden: Brill.

Dentons. 2016. China's supreme court and supreme procuratorate issue interpretation on bribery laws. 18 May.

<http://www.dentons.com/en/insights/newsletters/2016/may/17/china-s-supreme-courtand-supreme-procuratorate-issue-interpretation-on-bribery-law $>$

Dobinson, Ian. 2013. The guilty plea: an Australian/Chinese comparison. In Comparative Perspectives On Criminal Justice In China, ed. Mike McConville and Eva Pils, 187-205. Elgaronline: Edward Elgar.

Dui Hua Foundation. 2012. China's new Criminal Procedure Law: death penalty procedures. Dui Hua Human Rights Journal. 3 April, <http://www.duihuahrjournal.org/2012/05/notadding-up-criminal-reconciliation.html>.

Dui Hua Foundation. 2013. Community correction expands as RTL contracts Dui Hua Human Rights Journal. 19 December, <http://www.duihuahrjournal.org/2013/12/communitycorrection-expands-as-rtl.html>

Dui Hua Foundation. 2014. Deciding death: how chinese judges review capital punishment cases. Dui Hua Human Rights Journal. 18 November, <http://www.duihuahrjournal.org/2014/11/deciding-death-how-chinese-judges.html $\geq$

Dui Hua Foundation. 2015. China adds life without parole to anti-corruption arsenal. Dui Hua Human Rights Journal. 17 September, <http://www.duihuahrjournal.org/2015/09/china-adds-life-without-parole-to-anti.html >

Fang, Meng. 2014. Xin xingsufa shishi hou jianyi chengxu kaizhan xianzhuang, cunzai wenti, yuanyin ji wanshan duice [Current situation, existing problems, causes and perfection of summary procedure since the implementation of new criminal procedure law - a case study of q county in Sichuan province]. Guizhou jingguan zhiye xueyuang xuebao [Journal of Guizhou Police Officer Vocational College] 4:35-40.

Fewsmith, Joseph. 2012. Social management as a way of coping with heightened social tensions. China Leadership Monitor, 36, <www.hoover.org/publications/china-leadershipmonitor/article/104226 $\geq$

Forsythe, Michael. 2011. China cracks down in wake of riots, bombings. Bloomsberg. 3 June, $<$ http://forum.prisonplanet.com/index.php?PHPSESSID=thed6tkInpvai8vg0jre7cum36\&topi c=210427.0; nowap $\geq$

Fourth Plenum Decision. 2014. Central Committee Decision on Some Major Questions in Comprehensively Moving Forward Governing the Country According to Law. $<$ http://news.xinhuanet.com/legal/2014-10/28/c_1113015330.htm $\geq$ (English translation at: <http://chinalawtranslate.com/fourth-plenum-decision/?lang=en $\geq$ )

$\mathrm{Fu}$, Hualing. 2015. Wielding the sword: president Xi's new anti-corruption campaign. In Greed, Corruption and the Modern State: Essays in Political Economy, ed. Susan RoseAckerman and Paul Lagunes, 134-159. Cheltenham UK: Edward Elgar.

Fu, Hualing. 2016a. Between deference and defiance: courts and penal populism in Chinese capital cases. In China's Death Penalty in Transition: Theory, Policy, Practice and Reform, ed. Bin Liang and Hong Lu, 274-299. New York: Columbia University Press.

$\mathrm{Fu}$, Hualing. 2016b. Building judicial integrity in China. Hastings International and

Comparative Law Review 39: 167-181. 
Fu, Hualing and Richard Cullen. 2008. 'Weiquan (rights protection) lawyering in an authoritarian state: building a culture of public-interest lawyering. The China Journal 59: 111-126.

Fu, Hualing and Richard Cullen. 2011. Climbing the weiquan ladder: a radicalizing process for rights-protection lawyers. The China Quarterly 205: 40-59.

Fu, Jin and Yan Yu. 2016. Jianshi yu goujian: xingshi sucai chengxu zhong bei zuisu ren de renquan baozhang [Perspective and construction: the human rights protection of the person being prosecuted under procedures for expedited criminal sentencin]. Zunzhong sifa guilü yu xingshi falü shiyong yanjiu [Applied Research into Respect for Rule of Law and Criminal law] 1074-1084.

Gong, Huawei. 2006. Qingzui xingshi zhengce yanjiu [A study of the criminal policy of minor crime] Tianjinshi zhengfa guanli ganbu xueyuan xuebao [Journal of Tianjin Administrative College of Politics and Law] 89(3): 8-12.

Guo, Xu. 2015. Feifa zhengju paichu guize dianxing anlie fenxi - yi j sheng $d$ shi sifa shixian wei yangben [Analysis of exemplary cases concerning the rules on excluding illegal evidence, taking judicial practice in city $\mathrm{d}$ in province $\mathrm{J}$ as sample]. Faxue zazhi [Legal Science Magazine] 1: 133-140.

Guo, Zhiyuan. 2014. Criminal procedure, law reform and stability. In The Politics of Law and Stability in China, ed. Susan Trevaskes, Elisa Nesossi, Sarah Biddulph and Flora Sapio, 250-287. Cheltenham UK: Edward Elgar.

Guo, Zhiyuan. 2015. Feifa zhengju paichu fanwei jieding de kunjing yu chulu [Plight and way out for exclusionary rule of illegally obtained confession and a probe into reform of criminal interrogation]. Zhengju kexue [Evidence Science] 23: 645-652.

Han, Xu. 2015. Xin xingzhi susongfa shishi yilai lüshi bianhunan wenti shizheng yanjiu: yi S sheng weili de fenxi [Empirical research on the difficulties of defense lawyers after the implementation of the new Criminal Procedure Law: analysis of S Province as an example]. Falü luntan [Legal Forum] 30(3): 134-141.

He, Ting. March 2012. The Practice and Legislation of Criminal Reconciliation in China. Conference proceedings, Melbourne Law School: 1-16.

He, Xin. 2007. Why did they not take the disputes? Law, power, politics in the decision making of Chinese courts. International Journal of Law in Context 3(3): 203-225.

$\mathrm{He}$, Xin. 2012. Black hole of responsibility: the adjudication committee's role in the chinese court. Law \& Society Review 46(4): 681-712.

Hernandez, Javier. 2016. Zhou Shifeng, Chinese lawyer, is sentenced to 7 years for subversion. The New York Times. 4 August, <http://www.nytimes.com/2016/08/05/world/asia/china-zhou-shifengsentence.html?_r=0 $\geq$

Heilmann, Sebastian and Elizabeth J. Perry. 2011. Mao's Invisible Hand: The Political Foundations of Adaptive Governance in China. Harvard, MA: Harvard University Press.

Hu, Shiyou. 2007. Wanshan 'yanjin xingxun bigong' falü zhidu - jian tan 'bu de bei qiangpo zi zheng youzui' [On improving the legal system of strict prohibition of extraction confession through torture]. Faxue zazhi [Law Science Magazine] 109-111. 
Human Rights Watch. 2015. Tiger chairs and cell bosses. Police torture of criminal suspects in China, <https://www.hrw.org/report/2015/05/13/tiger-chairs-and-cell-bosses/policetorture-criminal-suspects-china $\geq$

Jiang, Na. 2016. Wrongful Convictions in China: Comparative and Empirical Perspectives. Berlin: Springer.

Jin, Xueren. 2007. Xingxun bigong yanjiu [Research on Torture]. Beijing: Zhongguo jiancha chubanshe.

Johnson, David and Franklin Zimring. 2009. The Next Frontier: National Development, Political Change, and The Death Penalty in Asia. Oxford/New York: Oxford University Press.

Joint Measures. 2014. Zuigao renmin fayuan, zuigao renmin jianchayuan, gonganbu, sifabu, guanyu zai bufen dichu kaizhan xingshi anjian sucai shidian gongzuo de banfa [Supreme people's court, supreme people's procuratorate, ministry of public security and ministry of justice measures on launching trial work in some areas on procedures for expedited handling of criminal cases]. 22 August,

<http://www.lawinfochina.com/display.aspx?id=22582\&lib=law\&SearchKeyword=\&SearchC Keyword=>

Joint Opinion. 2016. Zuigao renmin fayuan, zuigao renmin jianchayuan, gonganbu, guojia anquanbu, sifabu, guanyu tuijin yishenpan weizhongxin de xingshi susong zhidu gaige de yijian [Opinions on promoting the reform of the trial-centered criminal procedural system jointly issued by Supreme People's Court, Supreme People's Procuratorate, Ministry of Public Security, Ministry of National Security, and Ministry of Justice]. 10 October, <http://politics.people.com.cn/n1/2016/1010/c1001-28765885.html> (English translation available at: <http://chinalawtranslate.com $>$ )

Keith, Ronald. 1994. China's Struggle for the Rule of Law. London: St Martin's Press.

Keith, Ronald and Zhiqiu Lin. 2009. Judicial interpretation of China's Supreme People's Court as 'secondary law' with special reference to criminal law. China Information 23: 223-255.

Keith, Ronald C, Zhiqiu Lin and Shumei Hou. 2014. China's Supreme Court. Abington Oxon, UK: Routledge.

Lam, Willy. 2009. The politicisation of China's law-enforcement apparatus. China

Perspectives 2: 42-51.

Leavenworth, Stuart. 2016. Christian church leader jailed in chinese human rights crackdown. The Guardian, 3 August, <https://www.theguardian.com/world/2016/aug/03/christian-church-leader-hu-shigenjailed-chinese-human-rights-crackdown>

Lewis, Margaret K. 2011. Controlling abuse to maintain control: the exclusionary rule in China. New York University Journal of International Law and Policy 43: 629-697.

Li, Anthony H.F. 2016. Centralisation of power- the pursuit of law-based governance: legal reform under the Xi administration. China Perspectives. 2: 63-68.

Li, Enshen. 2017. The rhetoric and practice of community corrections in China. Asian Journal of Criminology 12: 143-162.

Li, Fenfei. 2014. Zuigao renmin fayuan sixing hezhun chengxu xinsuo [New reflections on the SPC's death penalty review process] Guojia jianchaguan xueyuan xuebao [Journal of National Prosecutors College] 22(5): 24-32. 
Li, Fenfei. 2015. Lun 'biaoyanxing bianhu': zhongguo lüshi fating bianhu gongneng de yihua jiqi jiaozheng ['Performative defence': the heterization and correction of Chinese lawyers' in-court defence] Zhengfa luntan [Tribune of Political Science and Law] 33(3): 77-92.

$\mathrm{Li}$, Ling. 2015. Chinese characteristics of the socialist rule of law: will the fourth plenum cure the problems of the chinese judicial system? Asia Policy 20(1): 17-22.

Li, Ling. 2016. The rise of the discipline and inspection commission, 1927-2012 anticorruption investigation and decision-making in the Chinese communist party. Modern China 42(5): 447482.

Li, Na, Min Zhang, and Yuanyuan Sun. 2014. Laodong jiaoyang zhidu zhihou qingzui anjian kuaisu jianshen jizhi yanjiu [A study on the mechanism of expedited justice for minor criminal cases after abolition of the system of reeducation through labour]. Beijing jingguan xueyuan xuebao [Journal of the Beijing Police College] I(1): 14-19.

Li, Shuang. 2016. Youhua sifa zhiquan peizhi de lilun jieshi yu zhidu jiangou [Conceptual interpretation and systematic construction of the theory behind optimising the allocation of authority]. Fazhi yu shehui fazhan [Legal System and Social Development] 2: 58-65.

Li, Yuwen. 2014. The Judicial System and Reform in Post-Mao China: Stumbling Towards Justice. Abington Oxon, UK: Routledge

Liang, Bin. 2016. China's death penalty practice: working progress, struggle and challenges. In China's Death Penalty in Transition: Theory, Policy, Practice and Reform, ed. Bin Liang and Hong Lu, 1-30. New York: Columbia University Press.

Liang, Bin. 2016. Corruption and the death penalty. 29 July, <https://cpianalysis.org/2016/07/29/corruption-and-the-death-penalty/ $\geq$

Liang, Bin, and Ni He. 2014. Criminal defense in Chinese courtroom: an empirical inquiry. International Journal of Offender Therapy and Comparative Criminology, 58(10): 1230-1252.

Liang, Bin, Lu Hong and Ni He. 2016. Political embeddedness and its impact on Chinese criminal defense lawyers' professional practice: an empirical testing. European Journal on Criminal Policy and Research 22: 341-361.

Liebman, Benjamin L. 2011. A populist threat to China's courts?. In Chinese Justice: Civil Dispute Resolution in Contemporary China, ed. Margaret Y. K. Woo and Mary E. Gallagher, 269-313. Cambridge: Cambridge University Press.

Liebman, Benjamin. 2014. Leniency in Chinese criminal law? Everyday justice in Henan. Columbia Law School Public Law \& Legal Theory Working Paper Group 14-406: 1-79.

Liu, Guangsan and Yanxia Li. 2016. Woguo xingshi sucai chengxu shidian de fansi yu zhonggou [Reflections and on China's pilots of procedures for expedited sentencing in criminal cases] Faxue [Law Science] 2: 147-159.

Liu, Sida, and Terence C. Halliday. 2011. Political liberalism and political embeddedness: understanding politics in the work of Chinese criminal defense lawyers. Law \& Society Review 45(4): 831-865.

Liu, Sida, and Terence C. Halliday. 2016. Criminal Defense in China: The Politics of Lawyers at Work. Cambridge: Cambridge University Press. 
Long, Zongzhi. 2015. 'Yishenpan wei zhongxin' de gaige qi xiandu [Reforms and limitations of 'making the trial central to the process'] Zhongwai faxue [Peking University Law Journal] 27(4): 846-860.

Lubman, Stanley. 2012. China's criminal justice value system makes reform moot. The Wall Street Journal. 7 February, <http://blogs.wsj.com/chinarealtime/2012/02/07/chinascriminal-justice-value-system-makes-reform-moot>.

Lubman, Stanley. 2014. Anxiety trumps law in party's crackdown on activists. The Wall Street Journal. 4 February, <http://blogs.wsj.com/chinarealtime/2014/02/04/anxietytrumps-law-in-partys-crackdown-on-activists>.

Lu, Hong, Yudu Liu and Charlotte Hu. 2016. The criminal justice system and the death penalty. In China's Death Penalty in Transition: Theory, Policy, Practice and Reform, ed. Bin Liang and Hong Lu, 31-61. New York: Columbia University Press.

Mai, Jun. 2016. China executes man who killed official over his demolished home. South China Morning Post. 15 November,

$<$ http://www.scmp.com/news/china/society/article/2046164/china-executes-man-who-killedlocal-official-nail-gun-after-his $>$

Mattis, Peter. 2012. The foundations of China's future stability. Asia-Pacific Bulletin 149, <http://www.eastwestcenter.org/publications/foundation-chinas-future-stability>

Miao, Michelle. 2013. Capital punishment in China: a populist instrument of social governance. Theoretical Criminology 17: 233-250.

MOJ (Ministry of Justice). 2014. Sifabu guanyu qieshi fahui zhineng zuoyong zuohao xingshi anjian sucai chengxue shidian xiangguan gongzuo de tongzhi [Notice on effectively performing functions to do a good job of the work of pilots of procedures for expedited sentencing of criminal cases]. 11 October, <http://www.moj.gov.cn/index/content/201410/11/content_6357096.htm?node=7337>

McConville, Mike, Satnam Choongh, Pinky Dick Wan Choy, Eric Wing Hong Chui, Ian Dobinson, and Carol Jones. 2011. Criminal Justice in China: An Empirical Inquiry. Cheltehnam and Northampton: Edward Elgar.

MPS 2013. Guanyu jinyibu jiaqiang xingshi zhifa ban'an gongzuo qieshi fangzhi fasheng yuanjia cuo'an de tongzhi (Notice on further strengthening and improving the work of implementing the law in criminal matters and avoiding the occurrence of cases of miscarriages of justice]. 5 June,

<http://www.pkulaw.cn/fulltext_form.aspx?Db=chl\&Gid=210276>

Minzner, Carl. 2013. China at the tipping point?: The turn against legal reform. Journal of Democracy 24(1): 65-72.

Minzner, Carl. 2015. Legal reform in the xi jinping era. Asia Policy 20: 3-9.

Nesossi, Elisa. 2012. China's Pre-Trial Justice. Criminal Justice, Human Rights and Legal Reforms in Contemporary China. London: Wildy, Simmonds and Hill Publishing.

Nesossi, Elisa. 2015. Political opportunities in non-democracies: the case of chinese weiquan lawyers. International Journal of Human Rights 19: 961-978.

Nesossi, Elisa. (Forthcoming 2017a). The politics of torture and miscarriages of justice. Journal of Comparative Law 11. 
Nesossi, Elisa. (2017b). Wrongful convictions: the useful injustice? In Justice: The China Experience, ed. Flora Sapio, Susan Trevaskes, Sarah Biddulph and Elisa Nesossi, 141-167. Cambridge UK: Cambridge: Cambridge University Press.

$\mathrm{Ng}$, Kwai and Xin He. 2016. The limits of legal commensuration: blood money and negotiated justice in China. American Journal of Sociology 122(4): 1104-1143.

NPC. 2014. Guanyu shouquan zuigao renmin fayuan, zuigao renmin jianchayuan zai bufen diqu kaizhan xingshi anjian sucai chengxu shidian gongzuo de jueding [Decision on authorising the Supreme People's Court and Supreme People's Procuratorate to conduct pilots on expedited sentencing in criminal cases in some locations]. 6 June,

<http://www.npc.gov.cn/npc/xinwen/2014-06/28/content_1869454.htm>

NPC. 2016. Guanyu shouquan zuigao renmin fayuan, zuigao renmin jianchayuan zai bufen diqu kaizhan xingshi anjian renzui renfa congkuan zhidu shidian gongzuo de jueding [Decision on authorising the Supreme People's Court and Supreme People's Procuratorate to conduct pilots in some locations on the system of lenient punishment in criminal cases where guilt and punishment are accepted]. 4 September, <http://politics.people.com.cn/n1/2016/0904/c1001-28689379.html>

Pan, Jingui. 2015. Qingwei xingshi anjian kuaisu banli jizhi yanjiu [Research on the mechanism for expedited handling of minor criminal cases]. Beijing: Zhongguo jiancha chubanshe.

Peerenboom, Randall. 2015. Fly High the banner of socialist rule of law with chinese characteristics! What does the 4th Plenum Decision mean for legal reforms in China? Hague Journal on the Rule of Law 7(1): 49-74.

People's Daily. 2015. Lüshi de zhanchang ying zai fating [Lawyers' battlefield should be in court]. Renmin Ribao [People's Daily]. 12 July, <http://news.cnr.cn/native/gd/20150712/t20150712_519168729.shtml>

Phillips, Tom. 2015. Pu Zhiqiang given three-year suspended sentence. The Guardian. 22 December, <https://www.theguardian.com/world/2015/dec/22/pu-zhiqiang-chinesehuman-rights-lawyer-sentenced-to-three-years>

Pils, Eva. 2014. China's Human Rights Lawyers: Advocacy and Resistance. Abingdon: Routledge.

Pils, Eva. 2009. Rights activism in China: the case of lawyer Gao Zhisheng. In Building Constitutionalism in China, ed. Stéphanie Balme and Michael W. Dowdle, 243-260. New York: Palgrave MacMillan.

Political-Legal Committee. 2013. Zhongyang zhengfawei guanyu qieshi fangzhi yuanjiacuoa an de guiding [Provisions on preventing miscarriage of justice]. 2 March, <http://blog.sina.com.cn/s/blog_60d9a2d60101qrdn.html>

Qian, Gang. 2014. China's political discourse in 2013. China Media Project. 6 January, <http://cmp.hku.hk/2014/01/06/34866/>

Qiu, Xiude. 2008. Goujian fuhe zhongguo guoqing de feifa zhengju paichu guize de lifa jianyi [Legislative suggestions on the establishment of the rules for excluding illegal evidence suitable for China's circumstances]. In Feifa quzheng yu xingshi cuo'an wenti yanjiu [Analysis of the issue of illegal evidence and criminal miscarriages of justice], ed. Zhang Deli and Chen Lianfu. Beijing: Zhongguo jiancha chubanshe. 
Ran, Yanfei. 2009. When Chinese criminal defense lawyers become the criminals. Fordham International Law Journal 32(3): 988-1042.

Roberts, Dexter. 2014. 'Picking quarrels and provoking troubles' -- the crime sweeping China. Bloomberg. 13 May, <http://www.bloomberg.com/news/articles/2014-0512/picking-quarrels-and-provoking-troubles-the-crime-sweeping-china>

Roberts, Julian V. and Wei Pei. 2016. Structuring judicial discretion in China: exploring the 2014 sentencing guidelines. Criminal Law Forum 27: 3-33.

Rosenzweig, Joshua . 2011. Lawyers express criticism of criminal procedure law revision draft. 31 August, <http://www.siweiluozi.net/2011/08/lawyers-express-criticism-ofcriminal.html>

Rosenzweig, Joshua. 2013. Disappearing Justice: public opinion, secret arrest and criminal procedure reform in China. The China Journal 70: 73-94.

Rosenzweig, Joshua.D., Flora Sapio, Jiang Jue, Teng Baio and Eva Pils. 2013. Comments on the 2012 revision of the Chinese criminal procedure law. In Comparative Perspectives on Criminal Justice in China, ed. Mike McConville and Eva Pils, 455-503. Cheltenham UK: Edward Elgar.

Rosenzweig, Joshua. 2016. Residential surveillance. Evolution of a janus-faced measure. In Legal Reforms and Deprivation of Liberty in Contemporary China, ed. Elisa Nesossi, Sarah Biddulph, Flora Sapio and Susan Trevaskes, 79-94. New York and London: Routledge.

Rosenzweig, Joshua. 2017. State, society, and the justice debate in contemporary China. In Justice: the China Experience ed. Flora Sapio, Susan Trevaskes, Elisa Nesossi and Sarah Biddulph: 26-66. Cambridge UK: Cambridge University Press.

Seppanen, Samuli. 2016. Ideological Conflict and the Rule of Law in Contemporary China: Useful Paradoxes. Cambridge UK: Cambridge University Press.

Shen, Deyong. 2015 Lun yishenpan wei zhongxin susong zhidu gaige [Placing trials at the centre of procedural law reform]. Zhongguo faxue [Chinese Jurisprudence] 3: 5-6.

Shen, Yang and Jie Yang. 2015. Suqian jianli qingwei xingshi anjian kuaisu banli jizhi [Suqian establishes a mechanism for expedited handling of minor offences]. Jiangsu jingjibao [Jiangsu Economic Daily]. 8 July, B01.

Shi, Yanan. 2008. On restorative justice practiced in China - status quo, challenge and the future of victim-offender reconciliation. Frontiers of Law in China 3(2): 294-323.

Shi, Wei. 2015. Xingshi sucai chengxu cunzai de wenti ji wanshan jianyi [Existing problems and suggestions for improving procedures for expedited criminal judgment]. Jinnan daxue xuebao [Journal of Jinnan University] 34(6): 48-53.

Sorace, Christian. 2017. Communist party immunology. In China Story Yearbook 2016: Control ed. Jane Golley, Linda Jaivin and Luigi Tomba, 98-107. Canberra: ANU Press.

Southern Weekend. 2014. Sixing fahequan shangshou banign, zuigao fayuan ruhe daoxia liuren [Eight years now since return of review death penalty decision to the Supreme People's Court: how can people's lives be saved?]. Nanfang zhoumo [Southern Weekend]. 16 October, <http://www.infzm.com/content/104788 $\geq$

Southern Weekend. 2016. Sixing fuhe shangshou shinian: Ivshi neng wei sixingfan zuo shenme [Ten years since the return of exclusive authority to review death penalty decisions 
to the spc: what defence lawyers can do]. Nanfang zhoumo [Southern Weekend], 16 September, <http://www.infzm.com/content/119670 $\geq$

SPC. 2012. The Supreme People's Court Interpretation of the Application of the PRC Criminal Procedure Law (20 December). <http://chinalawtranslate.com/最高人民法院关于适用《 刑事诉讼法》的解释/?lang=en $\geq$

SPC. 2013a. Zuigao renmin fayuan guanyu qieshi jianxing sifaweimin dali jiaqiang gongzheng sifa buduan tigao sifa gongxinli de rugan yijian [Supreme People's Court Opinions on actual justice practice for the people, vigorously strengthening a fair judiciary and continuously increasing judicial credibility] Document No. 9. 2 September, <http://legal.china.com.cn/2013-10/28/content_30426034.htm $\geq$

SPC. 2013b. Zuigao Renmin fayuan guanyu jianquan fangfan xingshi yuanjiacuaoan gongzuo jizhi yijian [Supreme People's Court Opinions on the work of preventing miscarriages of justice]. 21 November, <http://www.chinacourt.org/law/detail/2013/10/id/147221.shtm>

SPC. 2015a. Zuigao renmin fayuan guanyu quanmian shenhua renmin fayuan gaige de yijian-renmin fayuan disi ge wunian gaige gangyao (2014-2018) [Supreme People's Court Opinions on comprehensively deepening reform in the people's courts comprehensively: outline of the fourth five-year reform of the people's courts (2014-2018)]. 25 February, $<$ http://www.court.gov.cn/zixun-xiangqing-13520.html $\geq$ (English Translation at: $<$ http://chinalawtranslate.com/court-reform-plan/?lang=en $\geq$ )

SPC. 2015b. Zuigao renmin fayuan guanyu banli sixing fuhe anjian tingqu bianhu lüshi yijian de banfa [Supreme People's Court measures for hearing defense attorney opinions in final review of death penalty cases]. 29 January, <http://www.court.gov.cn/zixun-xiangqing13169.html $\geq$ (English Translation at: $<$ http://chinalawtranslate.com/dpdefenseopinions/?lang=en>)

SPC. 2015c. Zhou Qiang: jiang dang de qunzhong luxian guanchuan renmin fayuan gongzuo quanguocheng [Zhou qiang: implementing the party's mass line in all areas of the work of the people's court]. <http://www.chinacourt.org/article/detail/2014/07/id/1349971.shtml>

SPC 2017. Zuigaofa fabu yi shenpan wei zhongxin xingsu zhidu gaige shishi yijian [Supreme People's Court implementing opinions on making the trial central to the criminal process]. 21 February 2017, <http://www.court.gov.cn/zixun-xiangqing-36362.html>

SPC White Paper. 2016. Judicial reform of Chinese courts. 3 March, <http://english.court.gov.cn/2016-03/03/content_23724636_3.htm>

SPC-SPP. 2016. Zuigao renmin fayuan, zuigao renmin jianchayuan guanyu banli tanwu huilu xingshi anjian shiyong falü ruogan wenti de jieshi [Supreme People's Court, Supreme People's Procuratorate interpretation on handling cases of corruption and bribery]. 28 March, <http://www.spp.gov.cn/zdgz/201604/t20160419_116381.shtml> (English Translation at: <http://chinalawtranslate.com/spcbribery2/?lang=en>1

SPC Monitor. 2015. Supreme People's Court $4^{\text {th }}$ five year plan sees the light of day. 26 February, <https://supremepeoplescourtmonitor.com/2015/02/26/supreme-peoplescourts-4th-five-year-reform-plan-sees-the-light-of-day/>

SPC Monitor. 2016a. Supreme People's Court tweaks capital punishment review procedure. 27 June, <https://supremepeoplescourtmonitor.com/category/death-penalty/> 
SPC Monitor. 2016b. What China's judicial reform white paper says about it vision for judiciary. 12 April, <https://supremepeoplescourtmonitor.com/2016/04/12/what-chinasjudicial-reform-white-paper-says-about-its-vision-for-its-judiciary/>

SPP. 2006. Guanyu yifa kuaisu banli qingwei xingshi anjian de yijian [Opinion on expedited handling of minor criminal cases according to the law]. 6 June, <http://www.spp.gov.cn/site2006/2008-03-16/0002517405.html>

SPP. 2001. Guanyu yanjin jiang xingxun bigong jiangqu de fanzui xianyiren gongshu zuowei ding'an yiju de tongzhi [Notice on strictly prohibiting the use of confession extracted by torture as the basis for conviction]. 2 January, <http://www.spp.gov.cn/site2006/2006-0222/00025-152.html>

Su, Yang and Xin He. 2010. Street as courtroom: state accommodation of labour protest in South China. Law \& Society Review 44(1): 157-184.

Tanner, Murray Scot. 2007. Chinese Communist Party strategies for containing social protest. Paper delivered at $2^{\text {nd }}$. Berlin Conference on Asian Security (Berlin Group).

Third Plenum Decision. 2013. Decision of the Central Committee of the Communist Party of China on some major issues concerning comprehensively deepening the reform.

$<$ http://www.china.org.cn/china/third_plenary_session/2014-

01/16/content_31212602_9.htm>

Trevaskes, Susan. 2008. The death penalty in China today: kill fewer, kill cautiously. Asian Survey 43(3): 93-113.

Trevaskes, Susan. 2009. Restorative justice or mcJustice with Chinese characteristics? In Twenty-first Century China: Views from Australia, ed. Mary Farquhar, 77-96. Cambridge: Cambridge Academic Press.

Trevaskes, Susan. 2010a. The shifting sands of punishment in China in the era of harmonious society. Law and Policy 32: 322-361.

Trevaskes, Susan. 2010b. Policing Serious Crime in China: From Strike Hard to Kill Fewer. London: Routledge.

Trevaskes, Susan. 2012. The Death Penalty in Contemporary China. New York: Palgrave Macmillan.

Trevaskes, Susan. 2013a. China's death penalty: the Supreme People's Court, the suspended death sentence and the politics of penal reform. British Journal of Criminology 53(3): 482499.

Trevaskes, Susan. 2013b. Rationalizing stability preservation through Mao's not so invisible hand. Journal of Current Chinese Affairs 42(2): 51-77.

Trevaskes, Susan. 2014. Stability and harmony in death sentencing. In The Politics of Law and Stability in China, ed. Susan Trevaskes, Elisa Nesossi, Flora Sapio and Sarah Biddulph, 127-154. Cheltenham UK: Edward Elgar.

Trevaskes, Susan. 2015. Lenient death sentencing and the 'cash for clemency' debate. The China Journal, 73: 38-58.

Trevaskes, Susan. 2016a. Politico-legal discourse in punishing crime: using Mao to package the people's war on terror, harmonious justice and stability maintenance. The China Quarterly 226: 299-318. 
Trevaskes, Susan. 2016b. Creative death penalty reform in China: the case of drug transportation. Law and Policy 38(2): 143-161.

Trevaskes Susan and Elisa Nesossi. 2014. Under rule of law. In Civilising China: China Story Yearbook 2013, ed. Geremie R. Barmé and Jeremy Goldkorn, 202-229. Canberra: Australian Centre on China in the World, The Australian National University.

Trevaskes, Susan and Elisa Nesossi. 2015. The sword of discipline and the dagger of justice. In Shared Destiny: China Story Yearbook 2014, ed. Geremie R. Barmé, Linda Jaivin and Jeremy Goldkorn, 260-83. Canberra: ANU Press.

Trevaskes Susan and Elisa Nesossi. 2016. The fog of law. In Pollution: China Story Yearbook 2015, ed. Gloria Davies, Jeremy Goldkorn \&Luigi Tomba, 64-85. Canberra: ANU Press.

Trevaskes, Susan and Elisa Nesossi. 2017. Control by Law. In Control: China Story Yearbook 2016, ed. Jane Golley, Linda Jaivin and Luigi Tomba, 42-59. Canberra: ANU Press.

Trevaskes, Susan, Elisa Nesossi, Sarah Biddulph and Flora Sapio. 2014. Framing the stability imperative. In The Politics of Law and Stability in China, ed. Susan Trevaskes, Elisa Nesossi, Sarah Biddulph and Flora Sapio, 269-283. Cheltenham UK: Edward Elgar.

Wang, Dongxiang. 2005. Xingshi jianyi chengxu shenpan zuzhi maoshi gaigeyi [Preliminary discussion of the organizational model for reform using simplified procedure in adjudicating criminal cases]. Zhengfa daxue Iuntan [Tribune of Political Science and Law] 23(1): 172-180.

Wang, Liang 2015. Chen Youxi tan zuigao fayuan sixing fuhe chengxu gaijin [Chen Youxi talks about improving the death penalty review process]. 2 February, $<$ http://www.glawyer.net/article/377.html>

Wang, Shumao 2015. Feifa zhengju paichu guize de sifa shiyong bianxi [Differentiate and analyse the judicial use of the rules on the exclusion of illegal evidence] Zhengzhi yu falü [Politics and Law] 7: 151-61.

Wei, Dong. 2015. Woguo feizhi laojiao yihou de baoan chufen gaige [Reform of the security punishment after China's abolition of re-education through labour] Sichuan Daxue xuebao [Journal Of Sichuan University] 1: 81-88.

Wen, Philip. 2016. Legal rights activist Zhai Yanmin found guilty of subverting the Chinese state. The Sydney Morning Herald. 3 August, <http://www.smh.com.au/world/legal-rightsactivist-zhai-yanmin-found-guilty-of-subverting-the-chinese-state-20160802-gqjhqb.html>

Woo, Margaret Y.K. 2013. Bounded legality: China's developmental state and civil dispute resolution. Maryland Journal of International Law 27(1): 235-262.

Xinhua. 2013. Zuigao renmin fayuan yanjiushi zhuren huyunteng tan jiaqiang gongzheng sifa tigao gongxinli [Head of Supreme People's Court research office Hu Yunteng talks about strengthening judicial fairness and improving public credibility]. 28 October, <http://news.xinhuanet.com/legal/2013-10/28/c_117906268.htm>

Xinhua. 2014a. 730,000 people in community correction in China. China News. 5 November, <http://www.china.org.cn/china/2014-11/05/content_33975046.htm>

Xinhua. 2014b. Tongyi sixiang kaiqi zhengfa gongzuo de xin hancheng [Unify your thinking, open up new passages for politico-legal work]. Renmin fayuanbao, 10 January, <http://news.xinhuanet.com/legal/2014-01/10/c_125983523.htm> 
Xing, Bingyin. 2016. Sixing fuhe huigui zuigao fayuan shinian: shaosha yidapiren, yingfou gaicheng sanshen yin zhenbian [Ten years since the return of the review and approval process to the Supreme People's Court: a large number have escaped execution, debates on whether or not China should install a third trial instance]. The Paper, <http://www.thepaper.cn/newsDetail_forward_1527775>

Yang, Dali. 2017. China's troubled quest for order: leadership, organization and the contradictions of the stability maintenance regime. Journal of Contemporary China 26(103): 35-53.

Yang,-, Yuguan and Chen Zinan.. 2015. On the question of exclusionary rule in China. China Legal Science 3: 3-23.

Zhang, Qianfang. 2015. Yanshen dao wangluo yanlun de xunxin zishi [Extending picking quarrels and provoking troubles to the internet]. Financial Times [Chinese]. 4 February, <http://www.ftchinese.com/story/001060493?full=y>

Zhang, Qianfan. 2016. Judicial reform in China. In China's Socialist Rule of Law Reforms Under Xi Jinping, ed. John Garrick and Yan Chang Benne, 17-29. London and New York: Routledge.

Zhang, Xiaodong. 2014. Xingshi sucaizhi duosha [How much do you know about speedy criminal determination] Fangyuan [Fangyuan Magazine] 15: 56-59.

Zhao, Bingzhi. 2006. Sixing gaige tansuo [Explorations in death penalty reform]. Beijing: Falü chubanshe.

Zhao, Bingzhi. 2012a. Zhongguo sixing zhidu gaige qianjing zhangwang [A look at prospects for reform in China's death penalty system]. Zhongguo falü [China law] 2: 28-33.

Zhao, Bingzhi. 2012b. Guanyu zhongguo xianjieduan shenyong sixing de sikao (Reflections on the cautious use of the death penalty in contemporary times.) Zhongguo faxue [Legal Science in China] 6: 5-22.

Zhao, Bingzhi and Yuan Bin. 2013. On the current situation and trends of China's criminal justice policies: making three typical death penalty cases a breakthrough point. China Legal Science 1(2): 3-24.

Zhou, Bin. 2016. Faxue zhuanjia jiedu tuijin yishenpan wei zhongxin de xingshi susong zhidu gaige yijian [Legal experts give their interpretation of the joint opinion 'placing the trial at the center' of the criminal process].10 October, Fazhibao [Legal Daily] <http://www.legaldaily.com.cn/index_article/content/2016-10/10/content_6831148.htm >

Zhao, Yusha. 2016. Lawyers rush to halt execution of villager who killed official over demolition. Global Times. 23 October, <http://www.globaltimes.cn/content/1013223.shtml>

*Sarah Biddulph's contribution was supported by a grant from the Australian Research Council FT130100412.

*Elisa Nesossi's contribution was supported by a grant from the Australian Research Council DE150101187. 


\section{University Library}

\section{- M M I N E R VA A gateway to Melbourne's research publications}

Minerva Access is the Institutional Repository of The University of Melbourne

Author/s:

Biddulph, S;Nesossi, E;Trevaskes, S

Title:

Criminal Justice Reform in the Xi Jinping Era

Date:

2017

Citation:

Biddulph, S., Nesossi, E. \& Trevaskes, S. (2017). Criminal Justice Reform in the Xi Jinping Era. China Law and Society Review, 2 (1), pp.63-128. https:// doi.org/10.1163/25427466-00201002

Persistent Link:

http://hdl.handle.net/11343/252821 